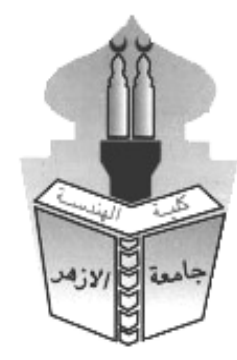

\title{
THE FUNCTION CHANGE OF SERVICE BUILDING VOIDS AND ITS EFFECT ON THE OPERATION STAGE (A CASE STUDY OF SERVICE BUILDINGS IN THE HOUSING DEVELOPMENT PROJECT IN MANSHAET NASSER, CAIRO GOVERNORATE)
}

\author{
Hossam Eldin Hassan Othman Elbrombaly* ${ }^{1}$, Akram Farouk Abdel Latif ${ }^{1}$ and \\ Dalia Ahmed Refaee Mohamed ${ }^{2}$ \\ ${ }^{1}$ Architecture Department, Faculty of Engineering, Ain Shams University, Cairo, Egypt. \\ ${ }^{2}$ Ministry of Housing, Utilities and Urban Communities, Cairo, Egypt. \\ * Corresponding Author E-mail: hos.borombaly@yahoo.com
}

\begin{abstract}
:
This subject dealt with the problem of functional change in the spaces of some service buildings during the operation phase, in the housing project for the development of Mansheyet Nasser in Cairo Governorate. Which is considered one of the economic housing projects in Egypt, that led to the decrease in the efficiency of the functional performance of those buildings and their failure, or their closure, leaving them deserted to become a hotbed for crimes and debris. Therefore, it was required to conduct a functional analysis of those existing buildings, along with an analysis of the new changes, to arrive at a proposed strategy in order to raise the efficiency of the functional performance of the existing service buildings. Which could be performed through several approaches to cover all aspects of the research, starting from the inductive approach, moving to the analytical approach, then reaching the deductive approach to suggest the required strategy.
\end{abstract}

\section{KEY WORDS : Functional Change, Conditions For Dealing With Existing Buildings, Treatments To Raise The Efficiency of Function Performance, Organizational Structure, Design Standards, Fire Protection Requirements, Functional Analysis, The Proposed Strategy For Service Buildings.}

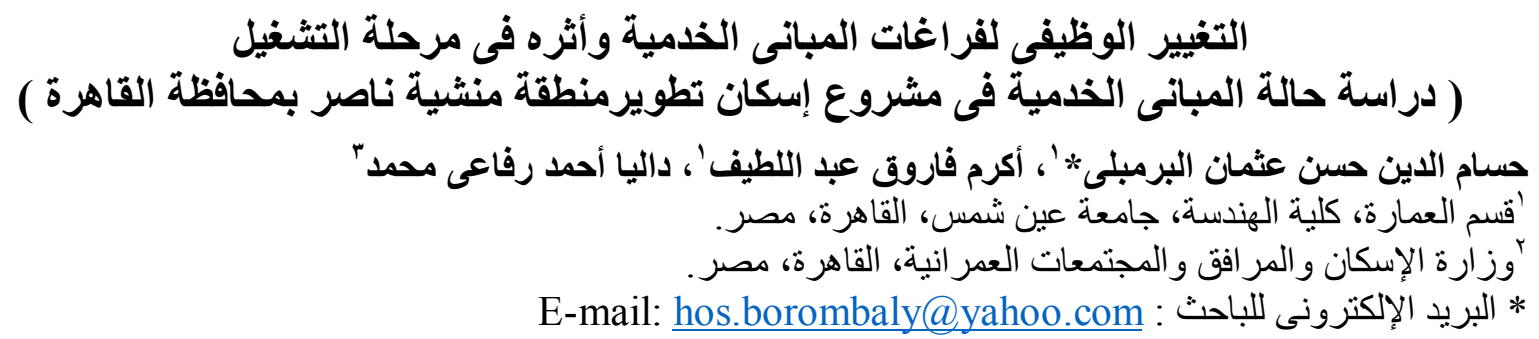

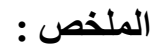
تناول هذا البحث مشكلة التغبير الوظيفى لفر اغات بعض المبانى الخدمية أثناء مرحلة التشغيل، فى مشروع إسكان تطوير

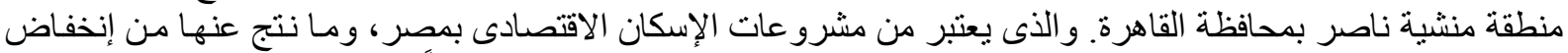

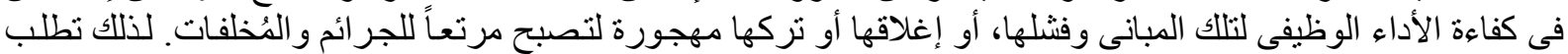




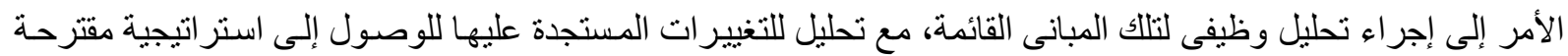

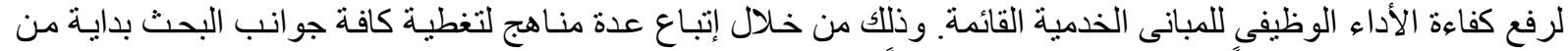

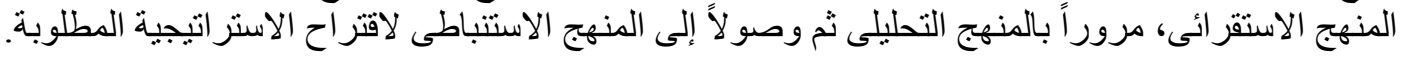

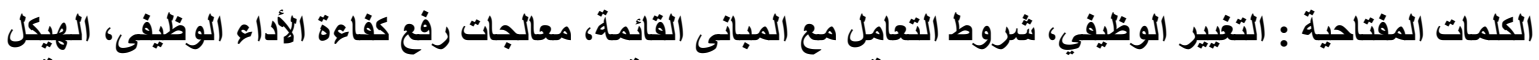

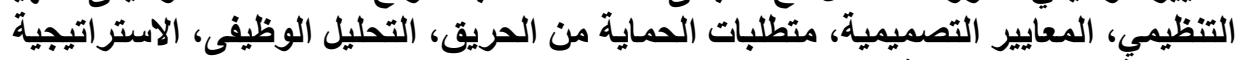
المقترحةٌ للمباني الخدمية.

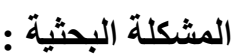

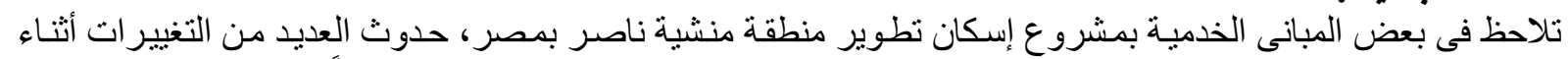

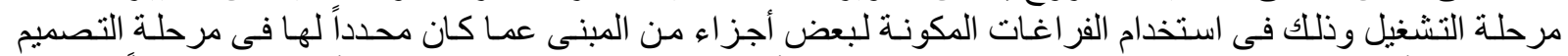

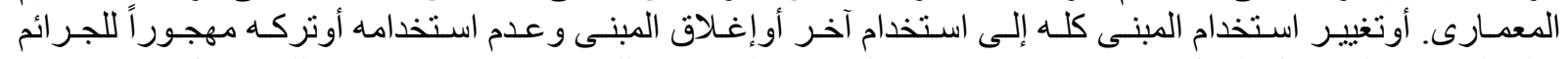

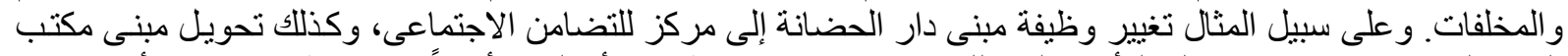

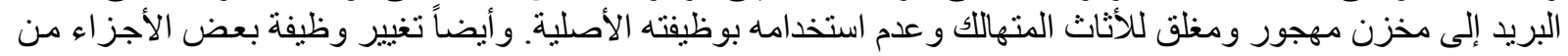

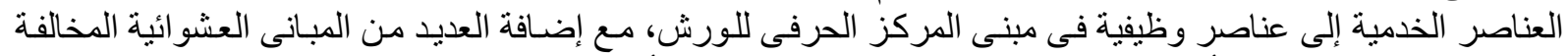

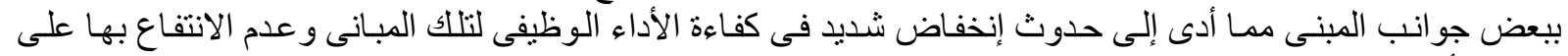

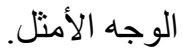

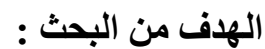

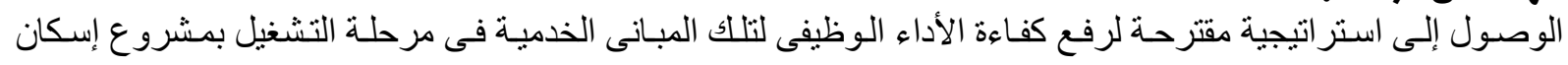

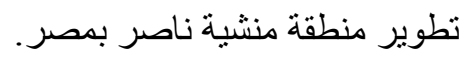

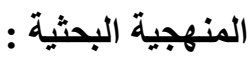

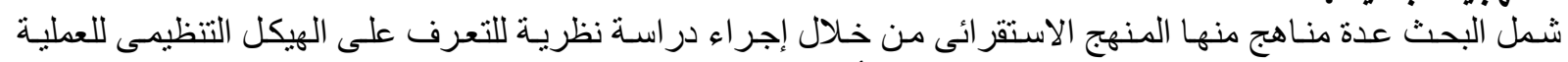

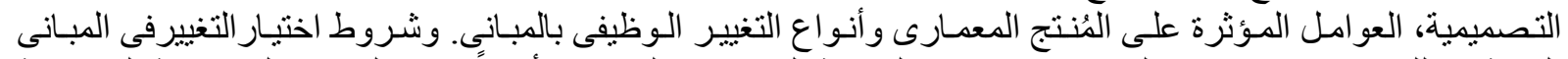

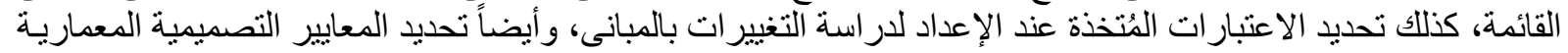

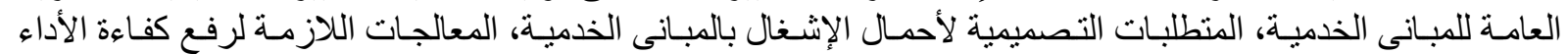

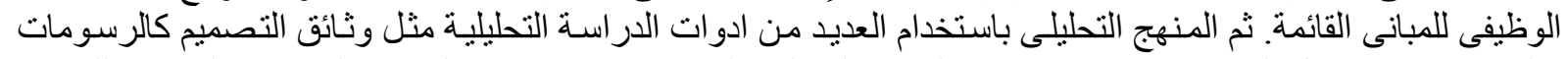

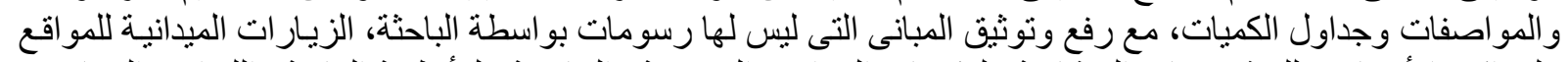

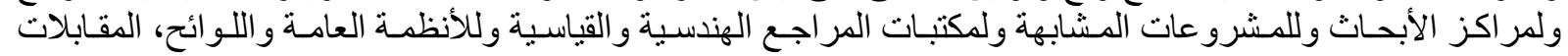

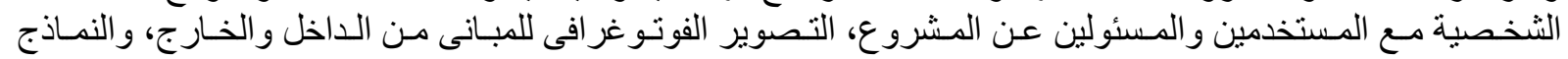

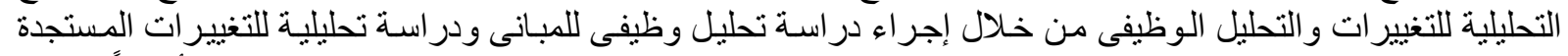

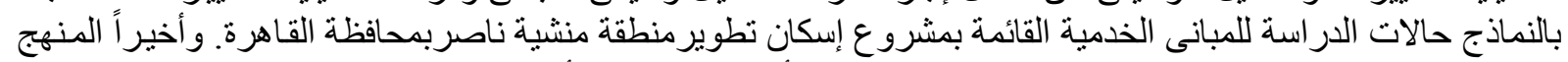

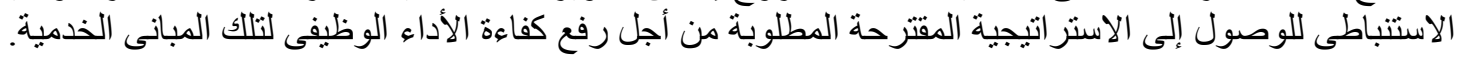

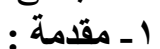

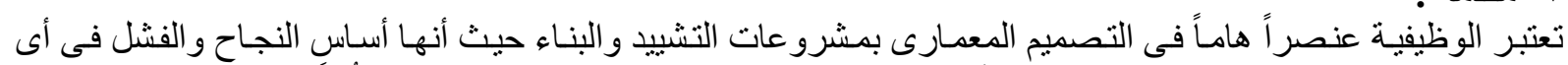

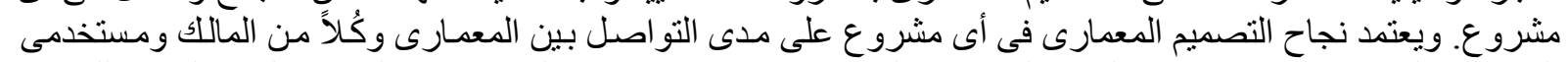

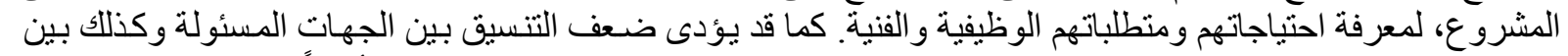

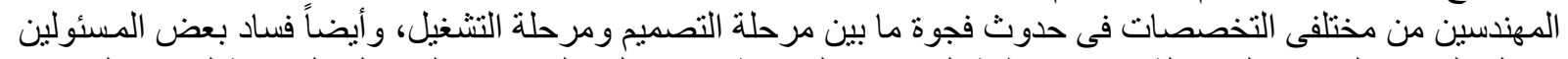

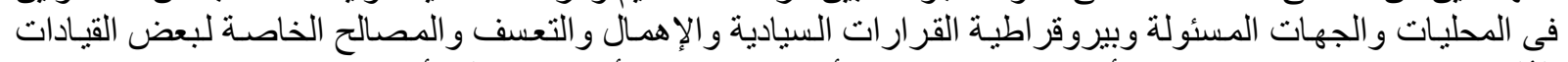

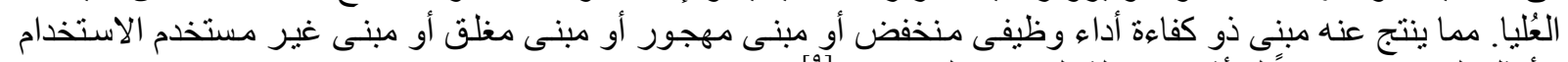

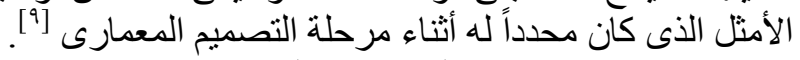

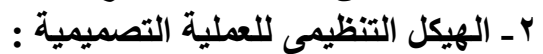
تتميز العملية التصميمية بتعدد وتداخل مر احلها ويمكن تحية تحديد الهيكل التنظيمى لعملية التصميم المعمارى قبل البدء فى

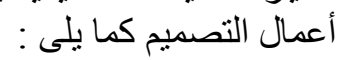

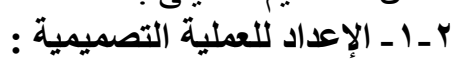

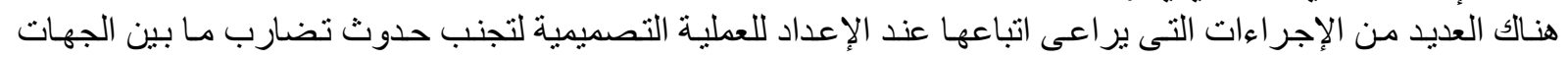

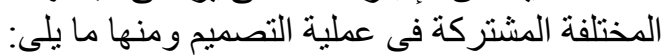

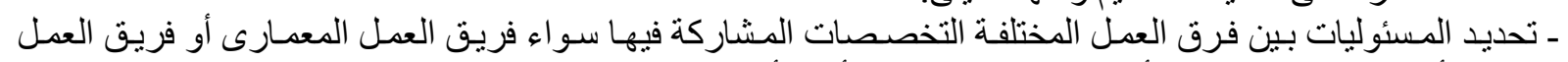

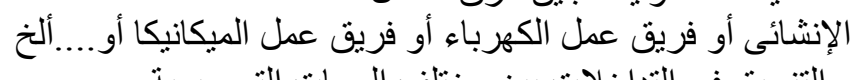

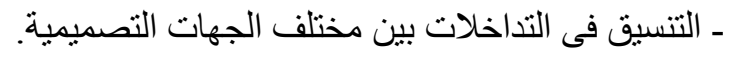


ير اعى عـ ألد تحديد أهدافت التصميم تخطيط مر احل التصميم إلى عدة مر احل مـع الالتزام بتحديد معايير جودة التصميم طبقاً لما يلى : لمنى

حيث يتم تقسيم كل مرحلة تصميم إلى العديد من المر احل ومنها مرحلة التعريف بالبرنامج التصميمى، مرحلة التحليل لجمع التحع

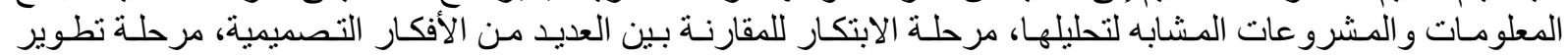

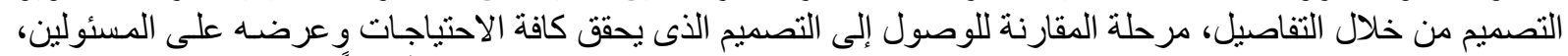

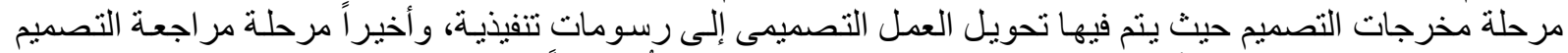
حيث يتم فيها اشتر اك جميع الأطر اف المشاركة فى العملية التصميمية كُلٍ طبقاً لتخصصه للتصنية للتطرق إلى المشاكل المختلفة

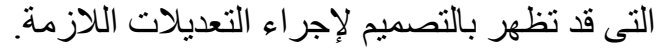

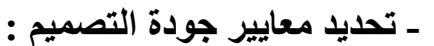

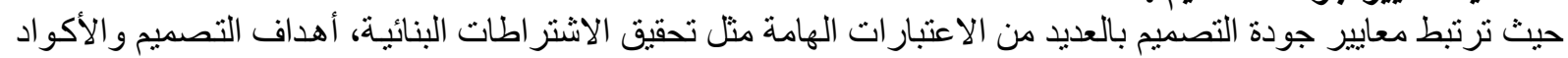

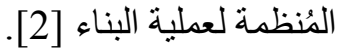

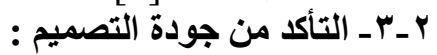
تبدأ هذه المرحلة فور الانتهاء من التهمل : العمل التصميمى، وتهدف إلى التأكد من مقدرة التصميم على تحقيق منطلبات الجودة

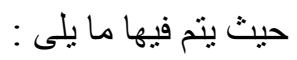
ـ اختيار هيئة لتقويم التصميم :

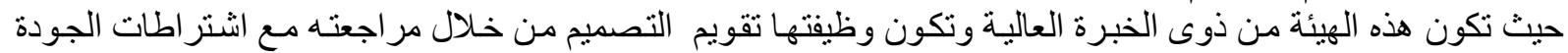
و المعايير التصميمية المحددة، لعمل التعديلات اللازمة التئة على التصديم.

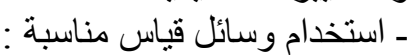

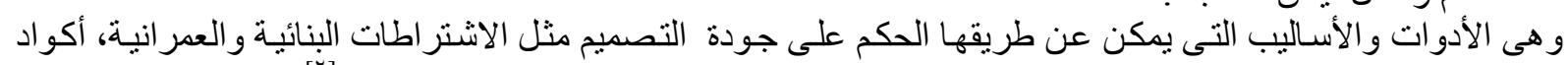

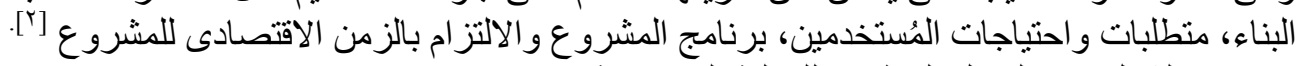
الهيكل التنظيمى للعملية التصميمية ويوضح الثكل (1) الهيكل التنظيمى للعملية التصميمية.

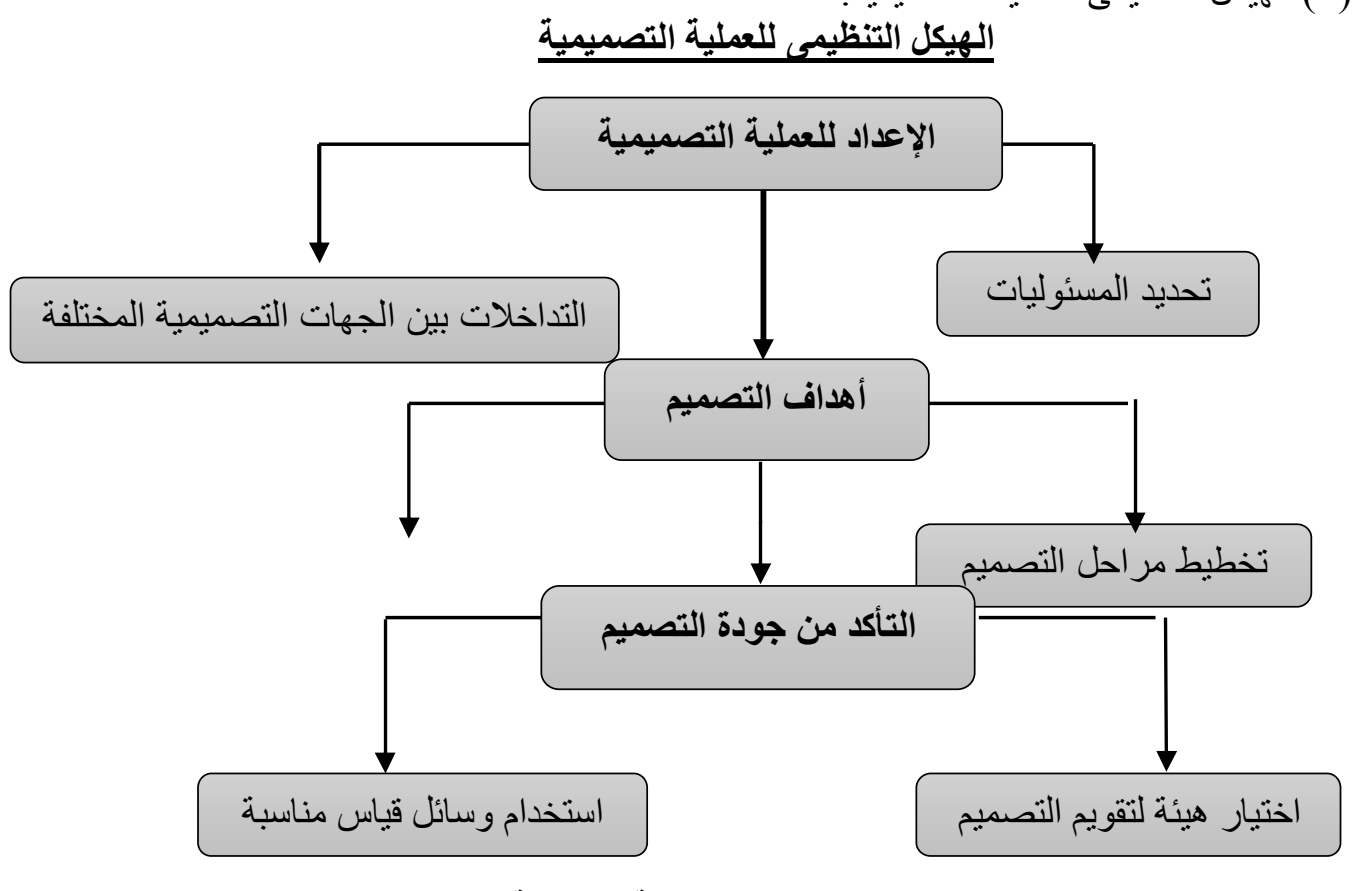

شكل (1) : الهيكل التظيمى للعملية التصميمية

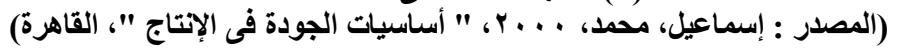

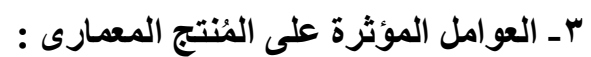

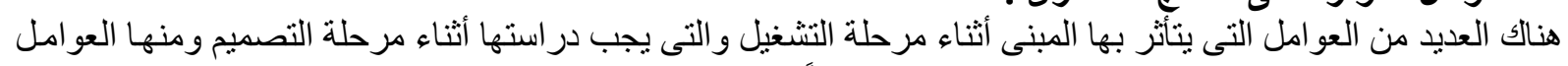
التصميمية و الاقتصادية و البيئية و التنظيمية و الاجتماعية طبقاً لما يلى : 


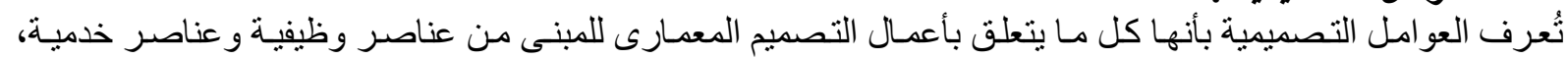

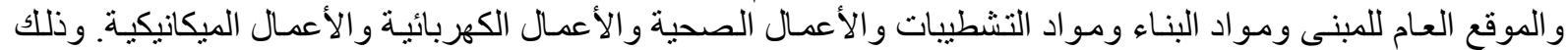

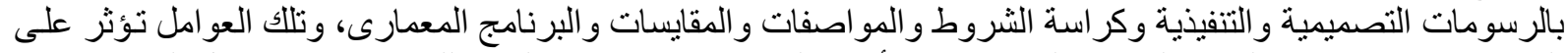

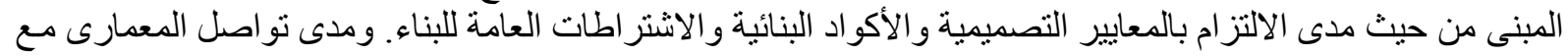

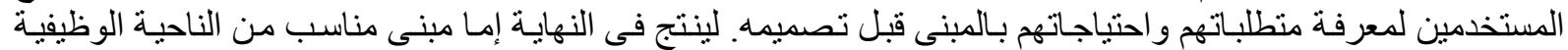

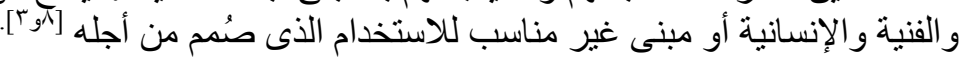

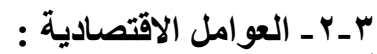

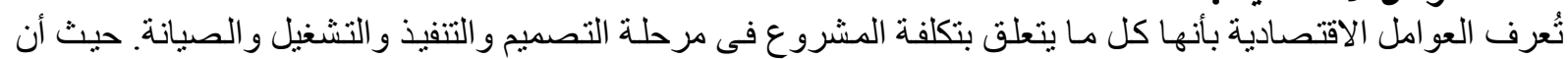

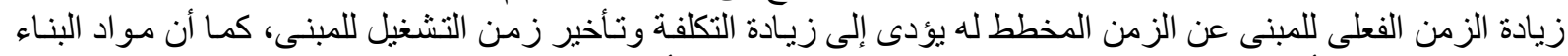

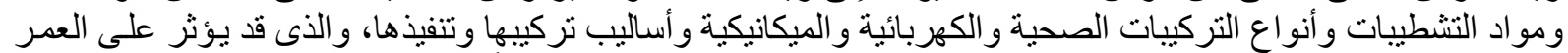

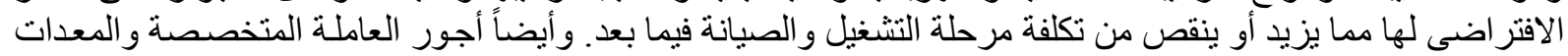

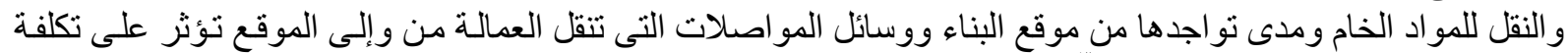

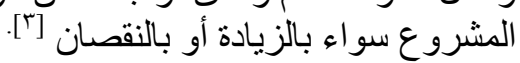

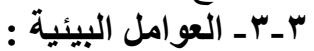

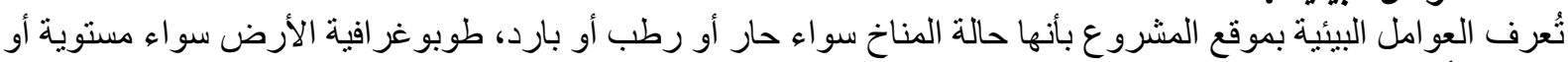

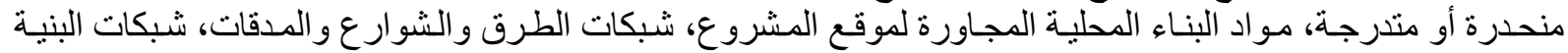

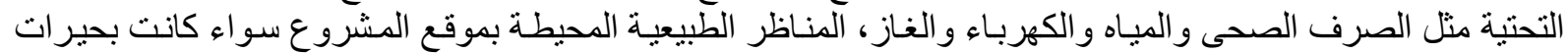

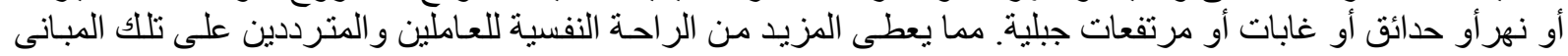

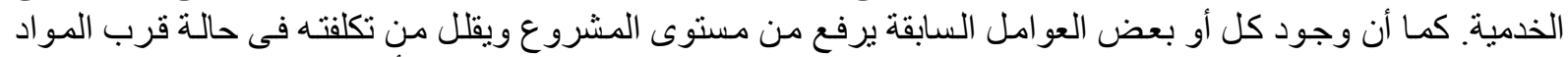

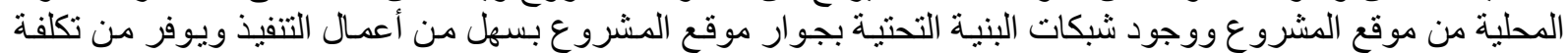

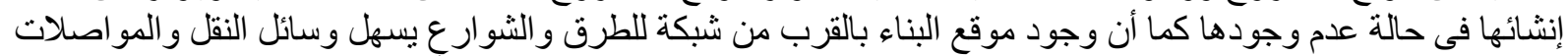

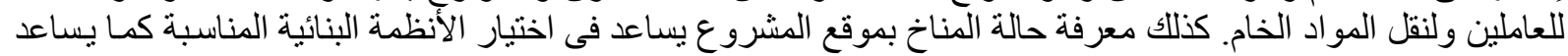

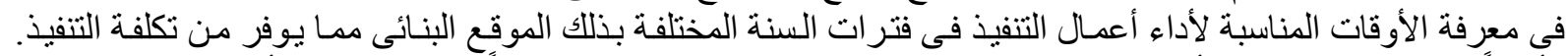

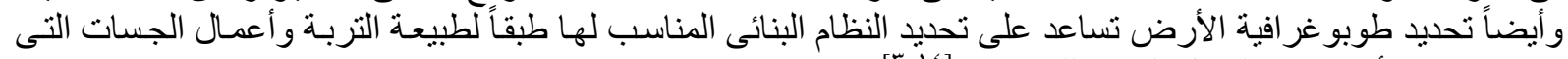

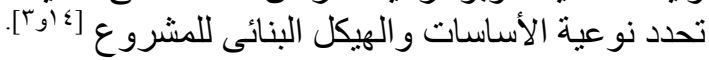

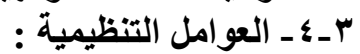

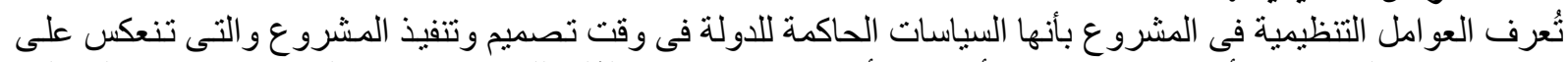

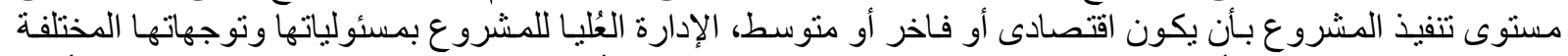

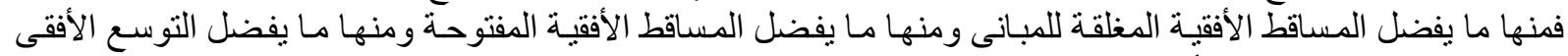

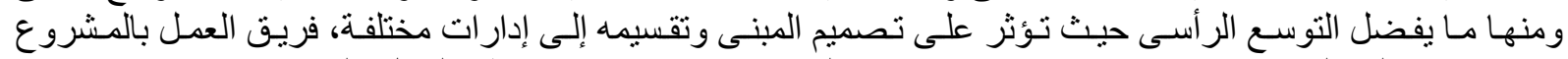

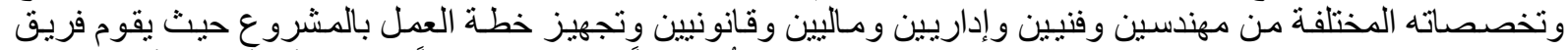

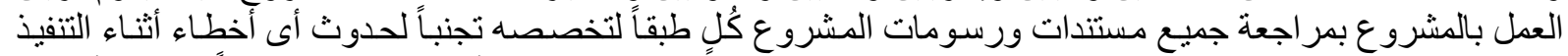

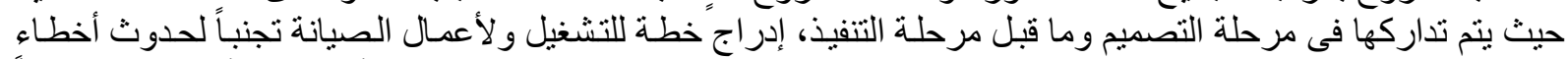

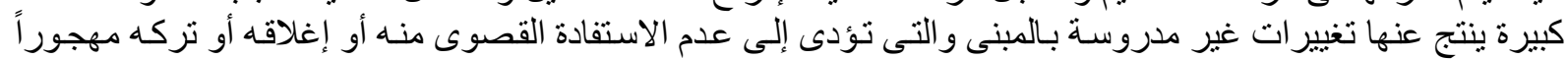

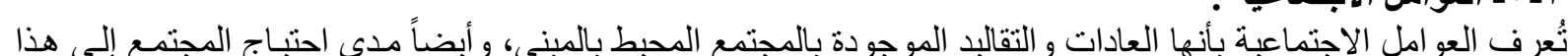

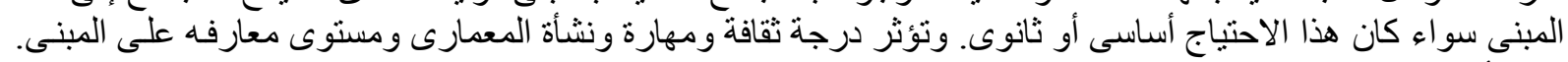

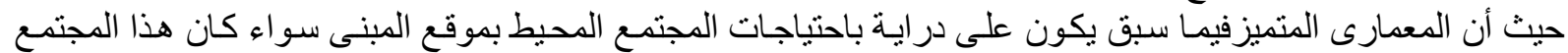

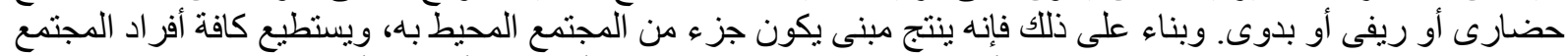

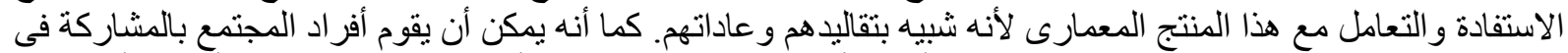

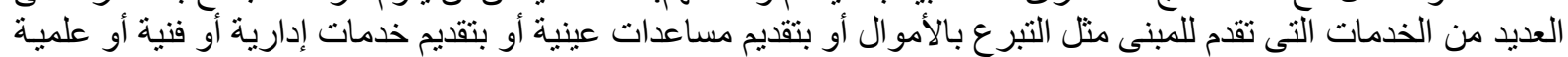

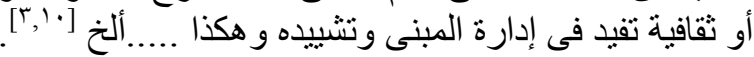


ويوضح الثكل (r) العو امل التى تؤثر على المُنتج المعمارى.

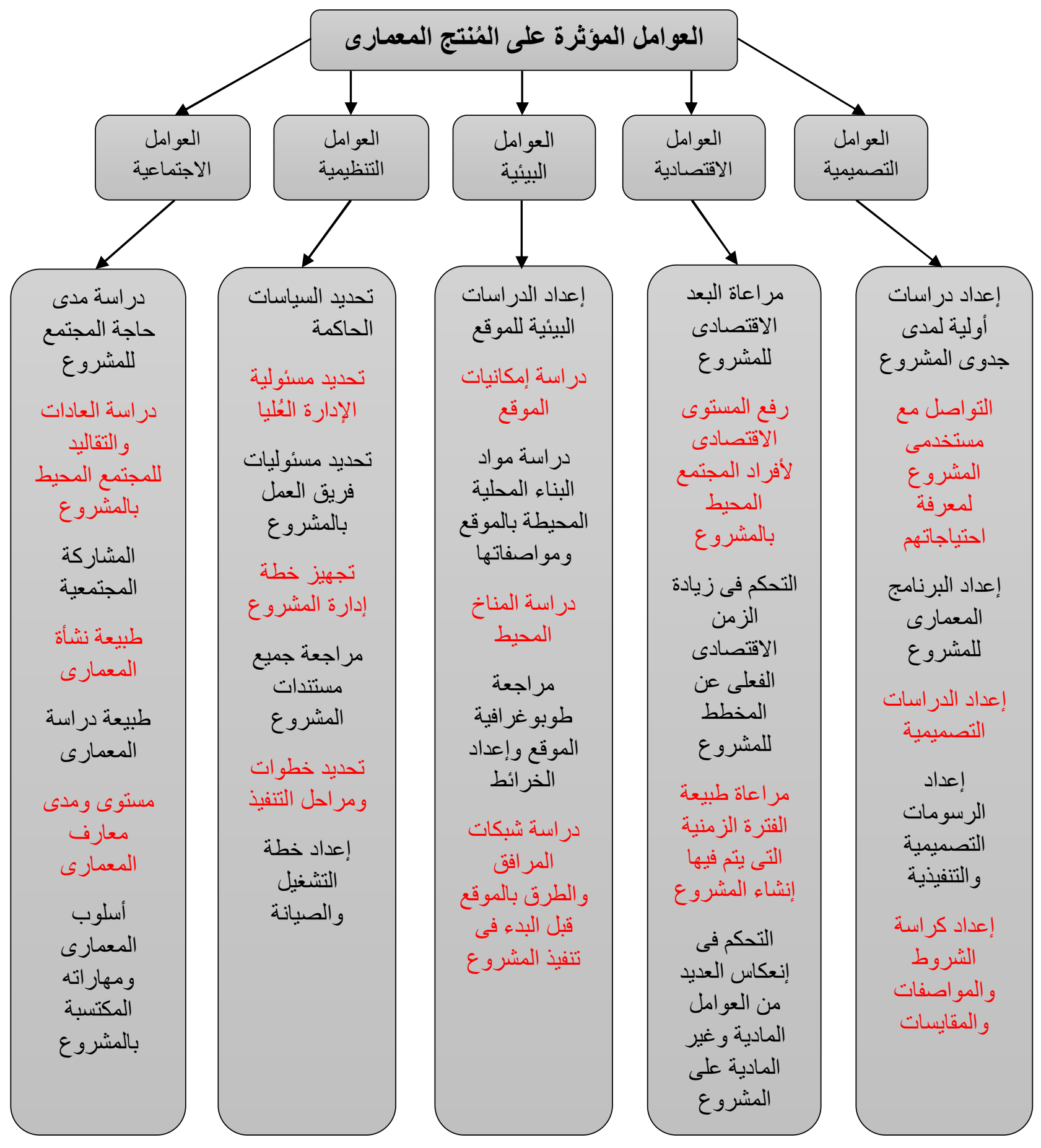

معايير تصميمية واقتصادية وبيئية وتنظيمية واجتماعية للمُنتج المعمارى للمشروع

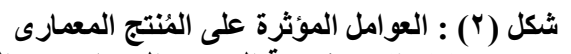

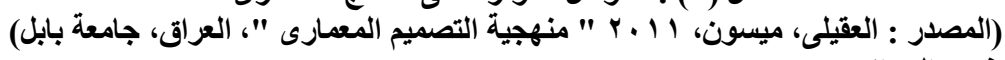

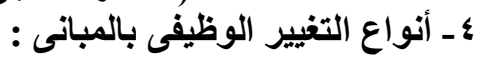

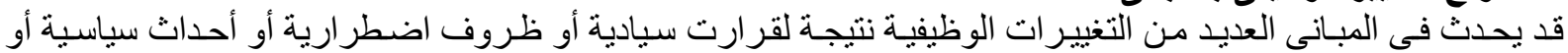

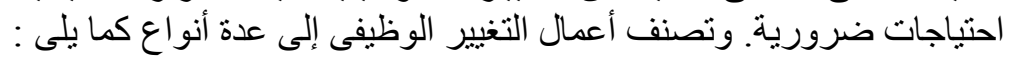

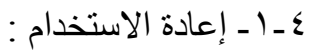




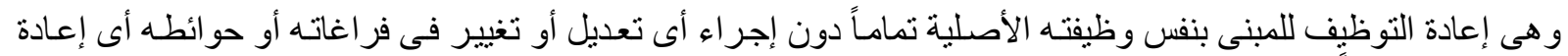

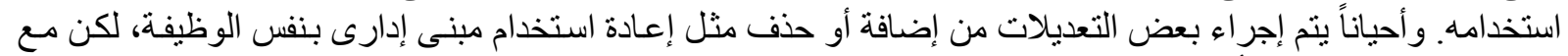

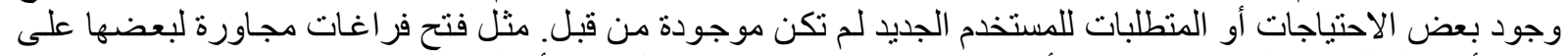

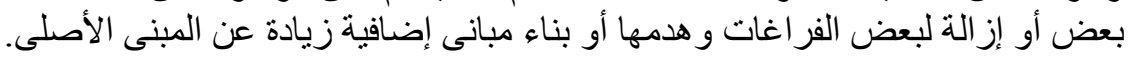

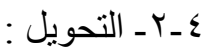

و هى تعتبر عملية إجر اء تغييرات كبيرة فى وظيفة المبنى وتصميمه وتخطيطه، مما يتطلب تحليل للهيكل الإنشائى لمعرفة

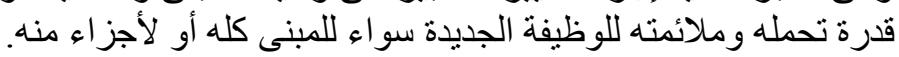

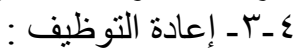
و هى العمليات المُتبعة لتغيير الوظيفة وتحويل المبنى إلى وظيفة أخرى غير التى صُمم من أجلها ويصاحب هذا التغيير فى

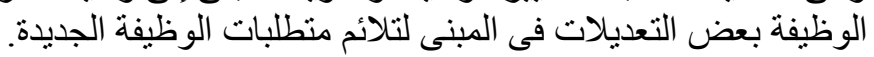

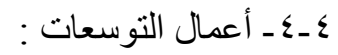

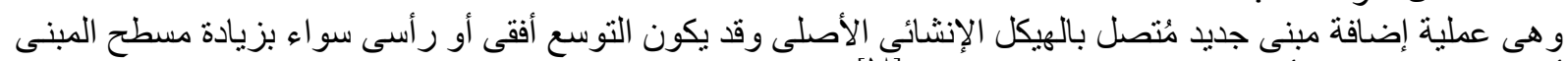

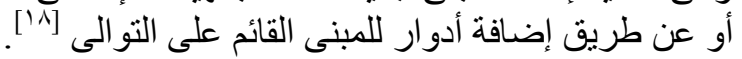
هـ شروط اختيار أساليب التغيير فى المبانى القائمة :

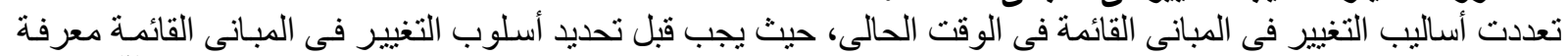

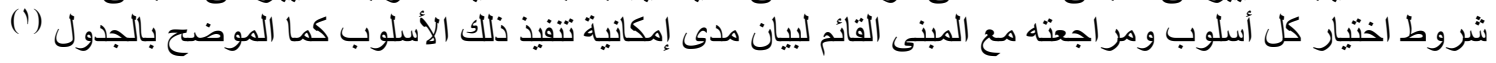
جدول (1) : شروط اختيار أساليب التغيير فى المبانى القائمة

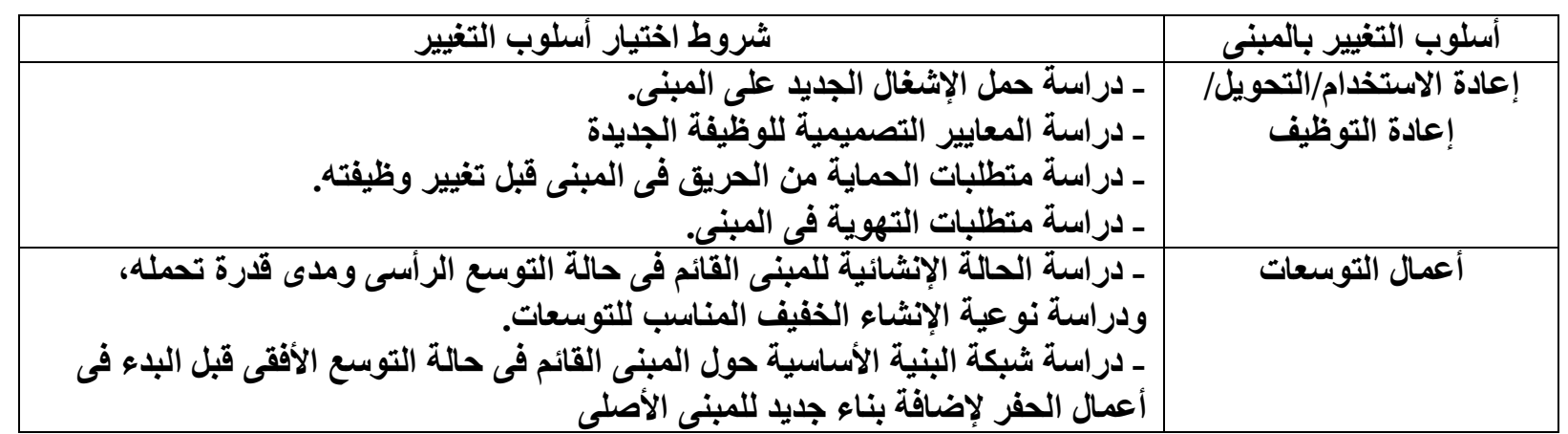

(Resource : Ebbert Thiemo, "Re - face Refurbishment Strategies For The Technical Improvement Of Office Façade", 2010)

جـ الاعتبارات المُتخذة عند الإعداد لاراسة التغييرات بالمبانى القائمة :

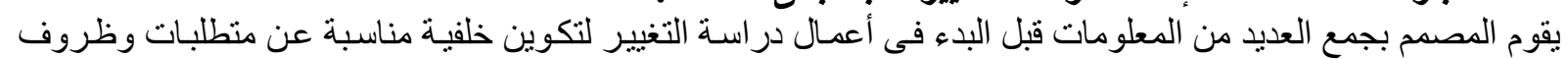

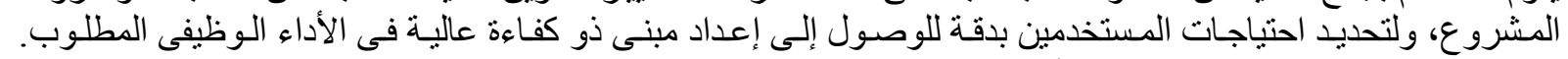

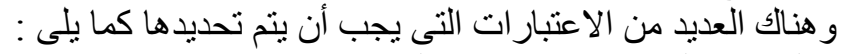

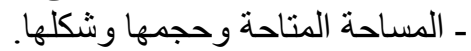
ـ ـ طبيعة العمل القائمة داخل الفراغ العزاغ.

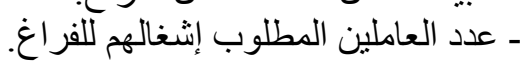

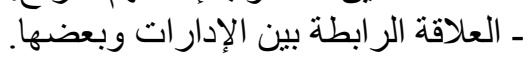

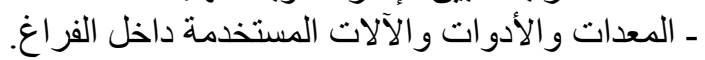

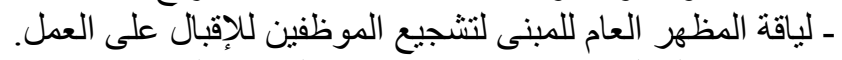

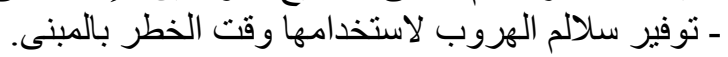

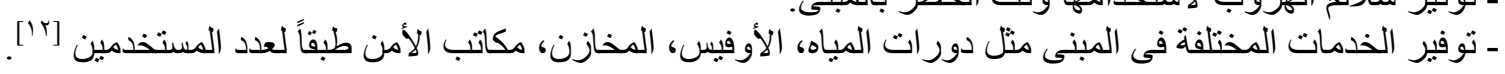

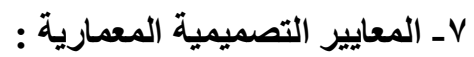

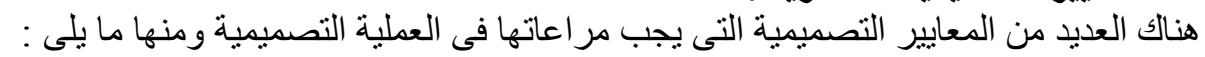

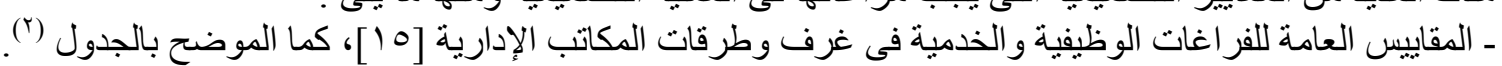

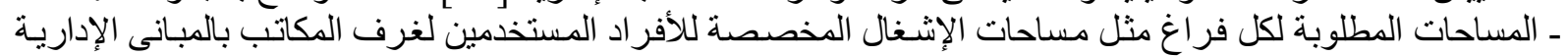

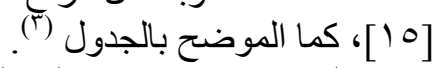

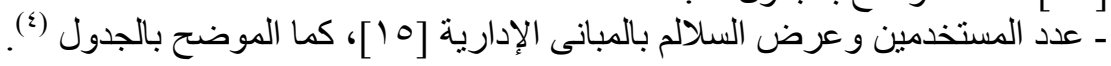




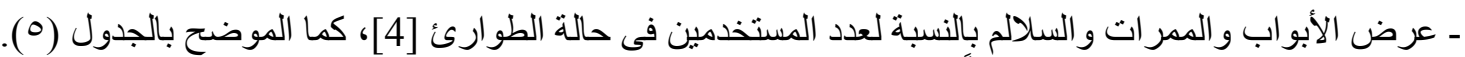

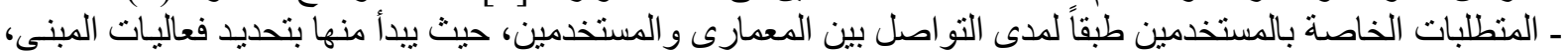

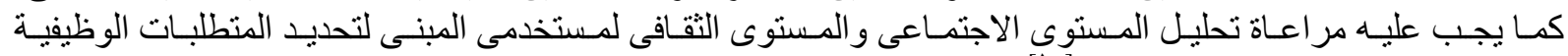

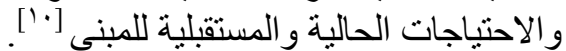

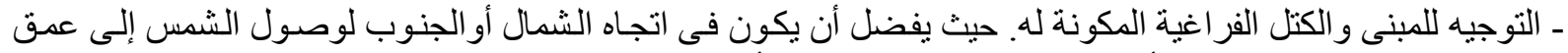

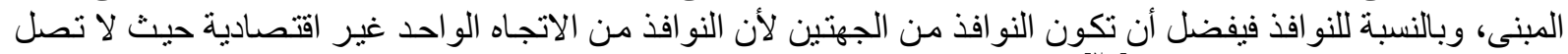

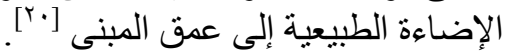

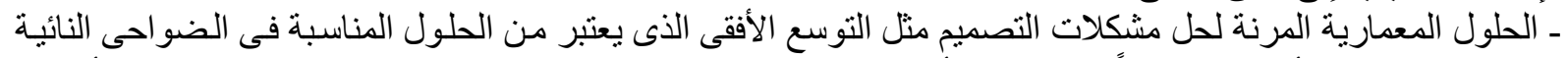

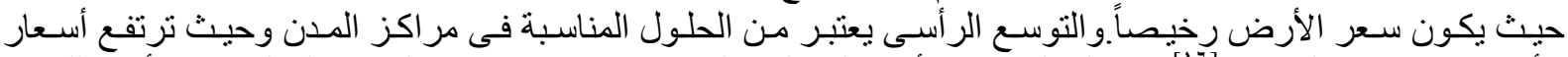

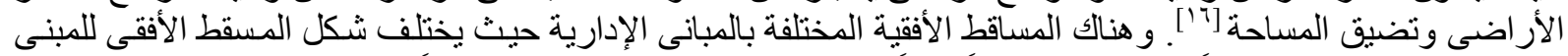

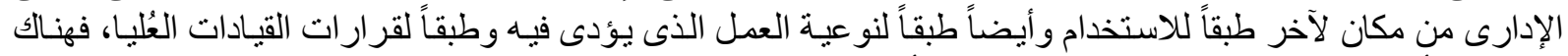

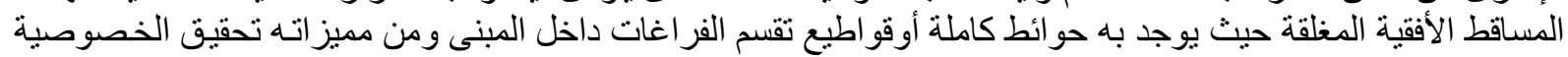

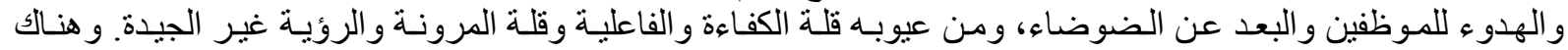

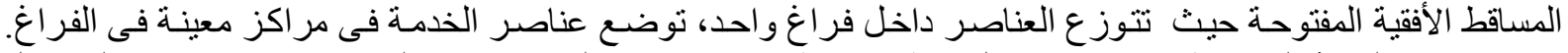

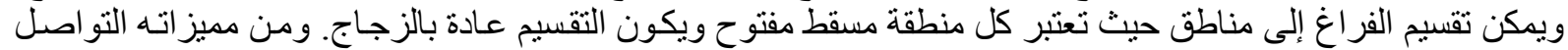

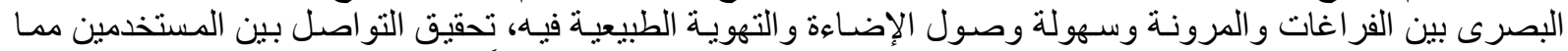

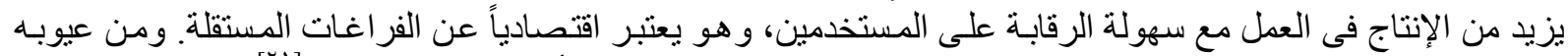

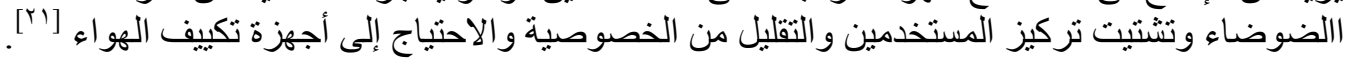

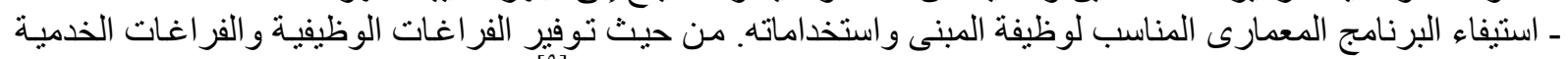

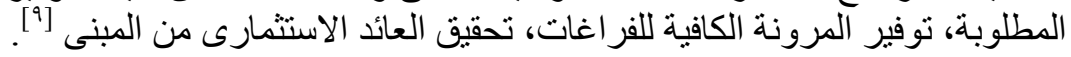

جدول (ץ) : المقاييس المعمارية فى غرف وطرقات المكاتب الإدارية

\begin{tabular}{|c|c|c|}
\hline البعد الأقصىى & البعد العادى بالمتر & المكان \\
\hline 9.10 & $V_{.0}-$ r.Vo & عمق الطرقة \\
\hline r... & 1.0 & عرض الطرقة \\
\hline $7 . \cdots$ & $r . r o-1 .$. & شبالك الوسط \\
\hline Y.O. & $r . \cdots-1.0$. & عرض الممر المفرد \\
\hline r.ro & $r .0 \cdot-1 . v_{0}$ & عرض الممر المزدوج \\
\hline $0 . \ldots$ & $\varepsilon \ldots-r_{.} \theta_{0}$ & ارتفاع الغرفة \\
\hline
\end{tabular}

(Resource : Baiche, B. “Neufert, Architects' Data”, 2011)

جدول (ّ) : مساحات الإثغال بالمكاتب الإدارية

\begin{tabular}{|c|c|}
\hline المساحة العادية المخصصة & المكان \\
\hline $9 . \cdots-7 . \cdots$ & موظف فى مكتب منفرد \\
\hline $0 . \ldots$ & موظف مع أخر بمكتب مشترك \\
\hline$\varepsilon \ldots$ & موظف في صالة للموظقين \\
\hline Y.O. & موظف فى صالة اجتماعات \\
\hline $1 . v \cdot$ & موظف بمكتب الكمبيوتر \\
\hline Y.r. & الموظف العادى بالمكتب \\
\hline Y.O. & الموظف المتعامل مع الجمهور \\
\hline •.... & مكتب السكرتارية \\
\hline Yo... - 10... & مكتب رئيس القسم \\
\hline Y^... & مدير بمكتب خاص \\
\hline $0 . \xi$. & الموظف بمكتب كبيز (عام) \\
\hline$V .0$. & الموظف بمكتب كبير (خاص) \\
\hline
\end{tabular}

(Resource : Baiche, B. “Neufert, Architects' Data”, 2011) 
جدول (§) : عدد المستخدمين وعرض السلالم بالمبانى الإدارية

\begin{tabular}{|c|c|}
\hline أقل عرض للسلالم & عدد المستخدمين \\
\hline 0. . 1 متر & . . ب فرد \\
\hline هץ. ا متر & أكثر من . ب فرد \\
\hline
\end{tabular}

(Resource : Baiche, B. “Neufert, Architects' Data”, 2011)

جدول (•) : عرض الأبواب والممرات والسلالم بالنسبة لعدد المستخدمين فى حالة الطوارئ

\begin{tabular}{|c|c|c|c|c|c|}
\hline \multicolumn{5}{|c|}{ عدد الأشخاص المستخدمين } & \multirow{2}{*}{ وسائل الذهوب } \\
\hline$\mu$ & Yo. & $r \ldots$ & 10. & $1 \ldots$ & \\
\hline 1.0. & م & .... & م.人⿻ & م. & والأبواب \\
\hline P... & م 1.70 & . & م.... & $\rho \cdot V \theta$ & السلالم \\
\hline
\end{tabular}

(المصدر : الكود المصرى لأسس التصميم واشتراطات التفيذ لحماية المنشأ من الحريق، الجزء الأول، المركز القومى لبحوث الإسكان والبناء،

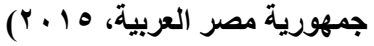

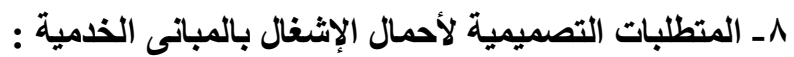

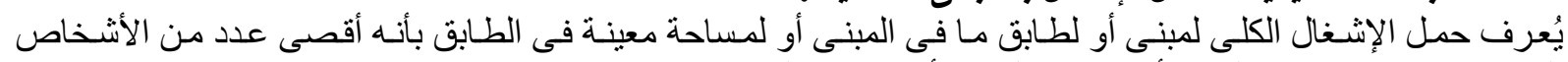

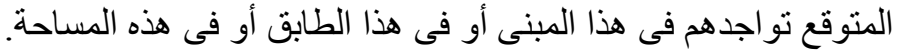

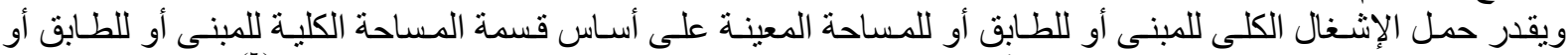

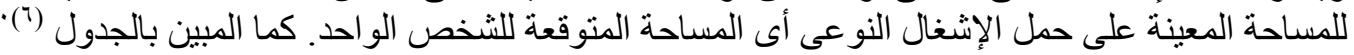

جدول (7) : حمل الإشغال النوعى طبقاً لنوع الإشغال

\begin{tabular}{|c|c|}
\hline حمل الإشغال النوعى مY / شخص & نوع الإشغال \\
\hline$\cdot . \varepsilon$ & مساحات وقوف تجمعات الأفر اد \\
\hline 1.90 & قاعات القراعة \\
\hline 0 & المحلات الحرفية / الورش البسيطة \\
\hline 1 . & المكاتب الإدارية والمهنية \\
\hline
\end{tabular}

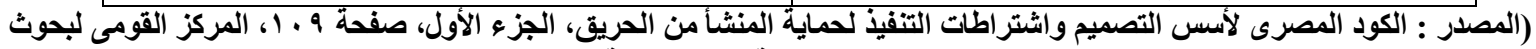

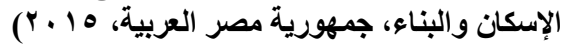

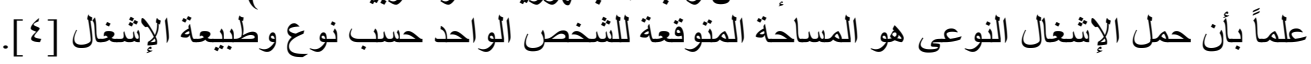

9ـ المعالجات اللازمة لرفع كفائة الأداء الوظيفى للمبانى الخدمية القائمة :

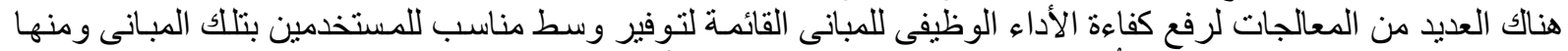

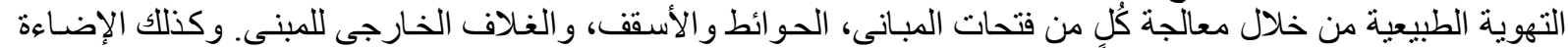

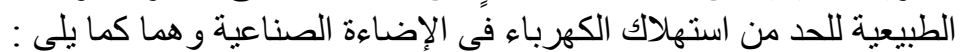

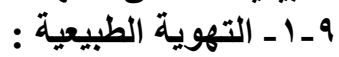
تتم معالجة التهوية الطبيعية بالمبانى القائمة لكُلاً من الفتحات و الحو ائط و الأسقف والغلاف الخارجى للمبانى وفقاً لحالة تلك

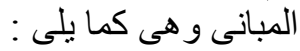

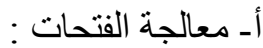

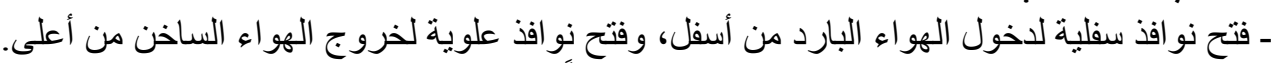

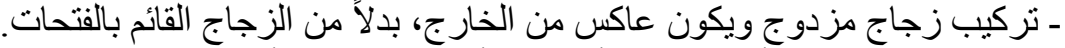

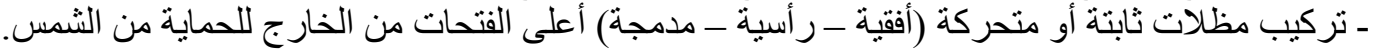

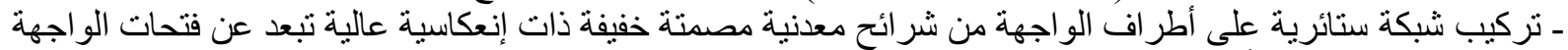

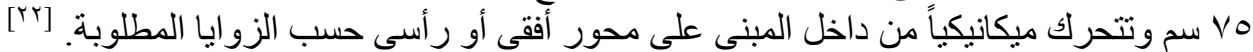

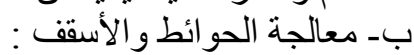

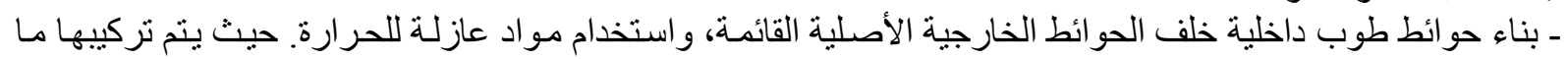
بين الحائطين قبل بناء الحوائط دائط الداخلية.

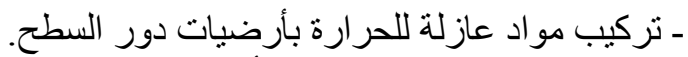

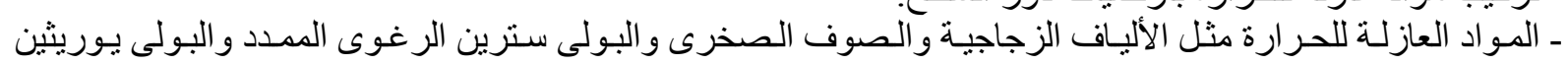

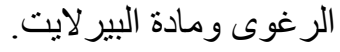




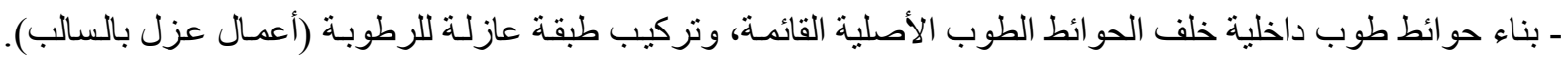

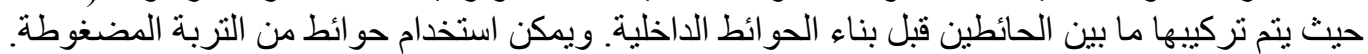

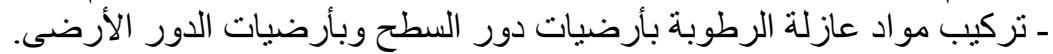

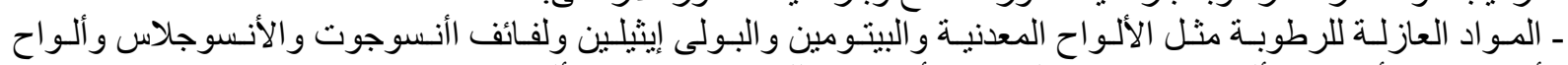

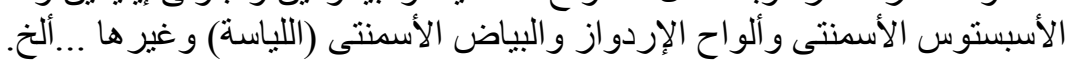

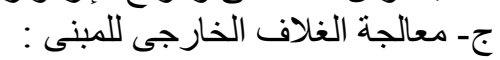

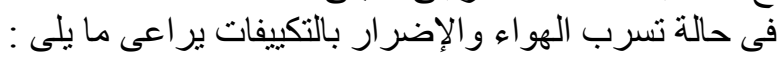

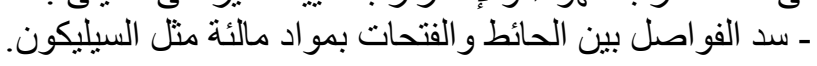

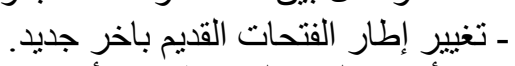

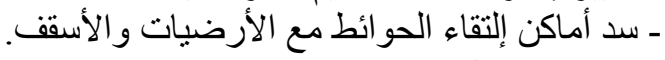

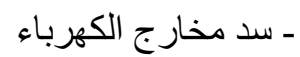
ـ سد مخارج طرد المطبخ و الحمام و الأوفيس.

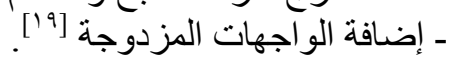

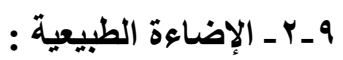

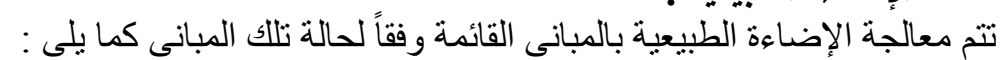

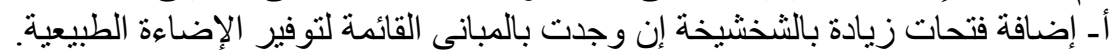

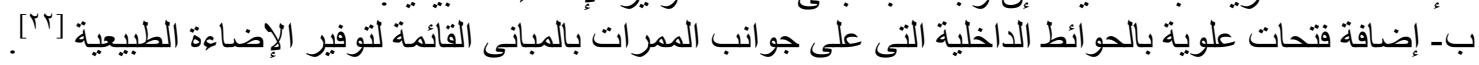

• إ- التحليل الوظيفى للمبانى القائمة :

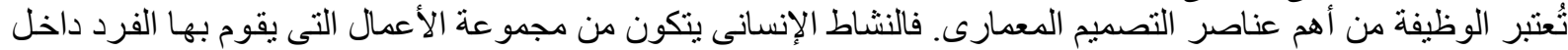

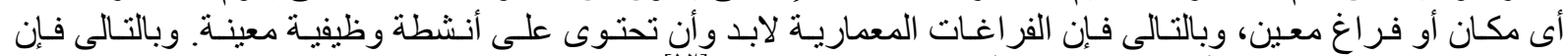

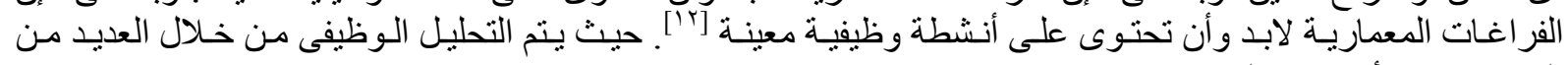

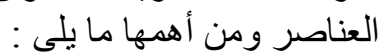

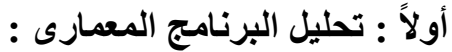

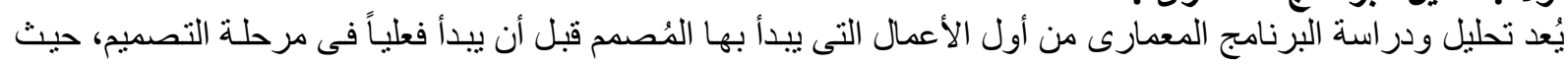

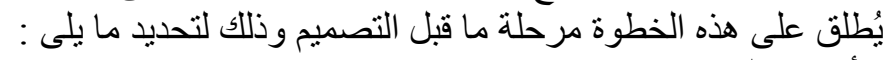

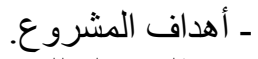

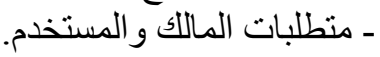

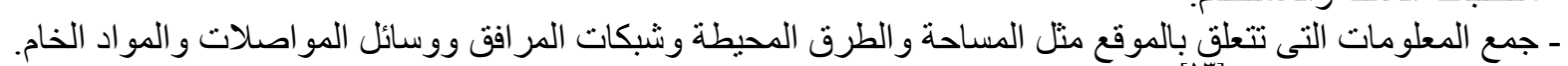

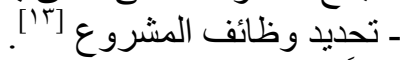

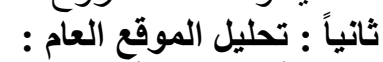

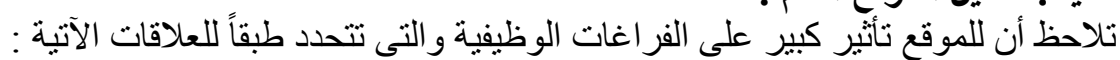

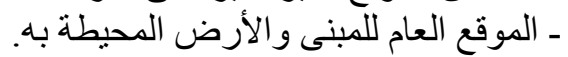

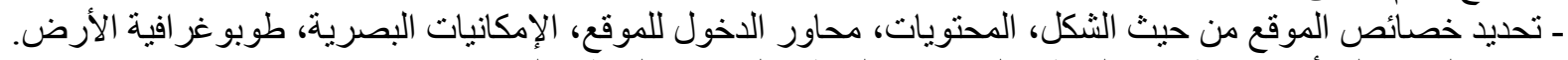

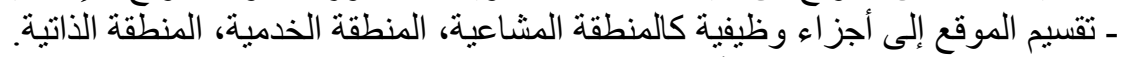

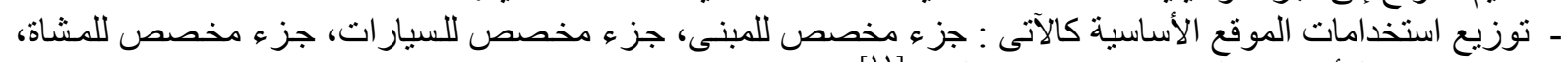

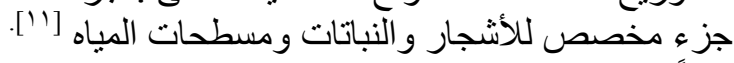

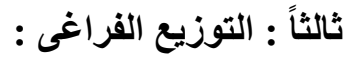

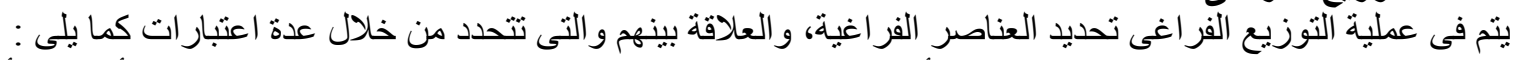

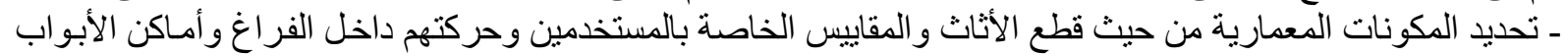

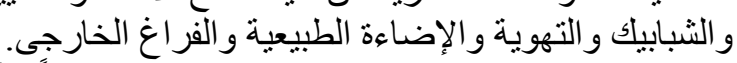

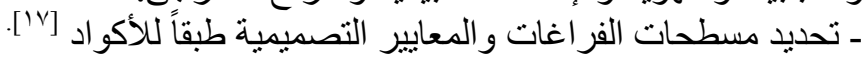

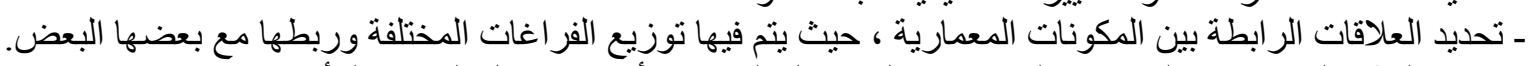

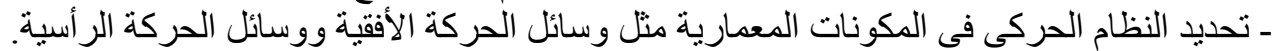

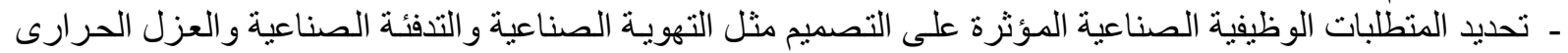
عزل الرطوبة و الإنارة الصناعية. 


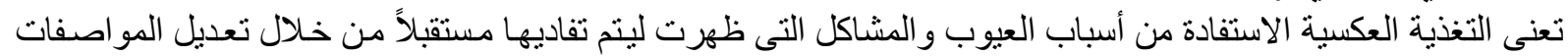

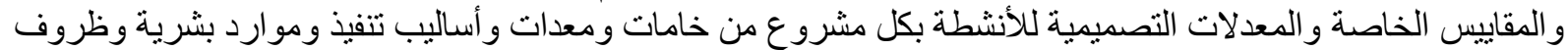

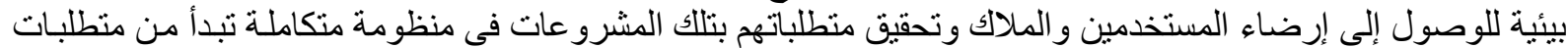

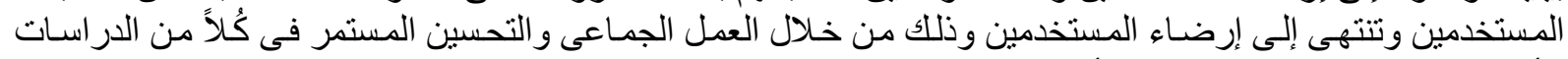

الأولية والتصميم و التنفيذ و التشغيل و أعمال الصيانة فى المشاريع المستقبلية [0].

r ا ـ دراسة حالة المبانى الخدمية بمشروع إسكان تطويرمنطقة منشية ناصر بمحافظة القاهرة :

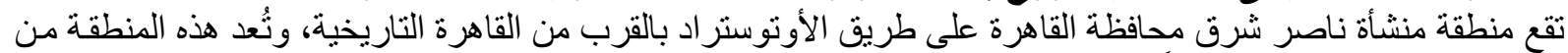

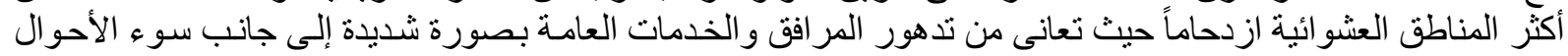

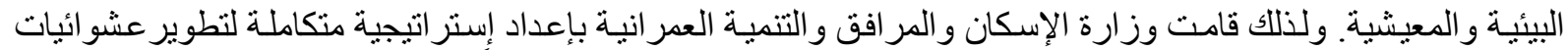

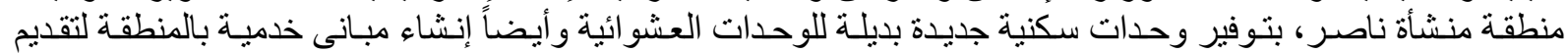

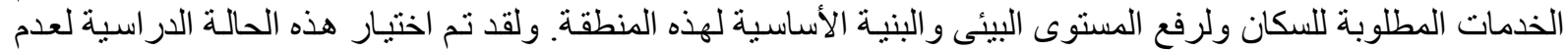

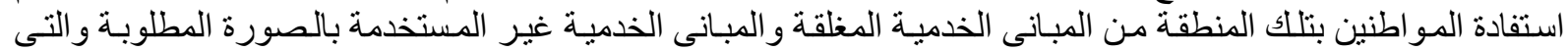
سوف توفر عليهم الكثير من الوقت و الجهد و التكلفة فى حالة انتقالهم إلى مبانى خدمية أخرى خار ج منطقة منشية ناصر [יآ]

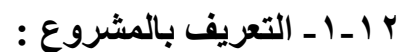

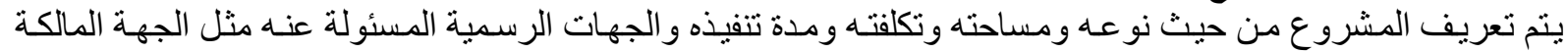

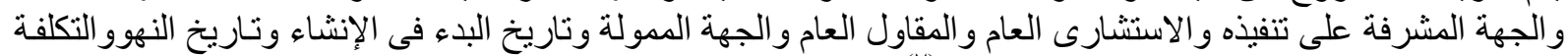

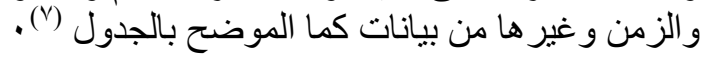

\begin{tabular}{|c|c|}
\hline 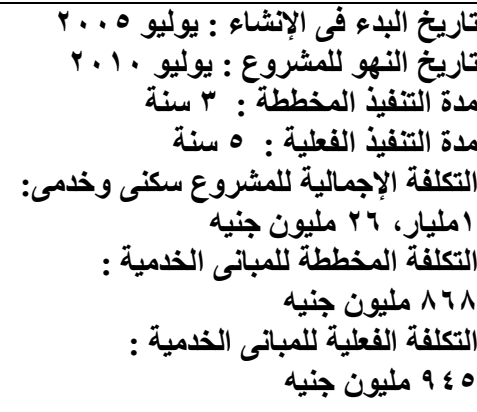 & 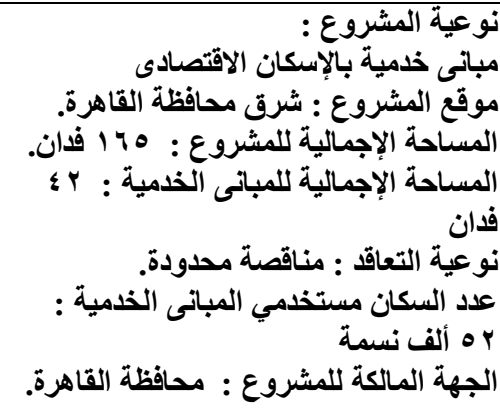 \\
\hline \multicolumn{2}{|c|}{ 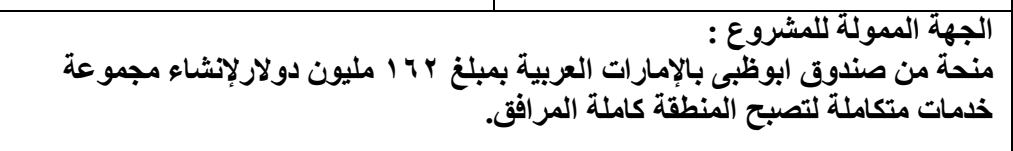 } \\
\hline & 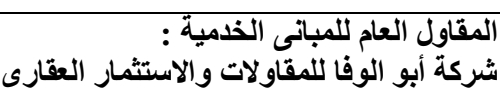 \\
\hline 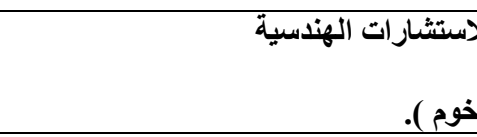 & 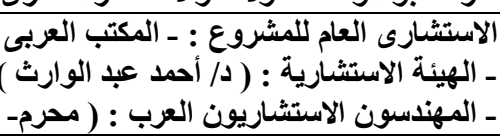 \\
\hline زارة الإسكان واي & تشفيذى لتعمير مشروعات القاهرة \\
\hline
\end{tabular}

(المصدر : جهاز تعمير مشرو عات القاهرة الكبرى، ؛ ا ب ب، إدارة المشروعات)

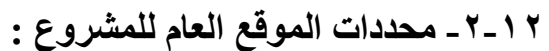

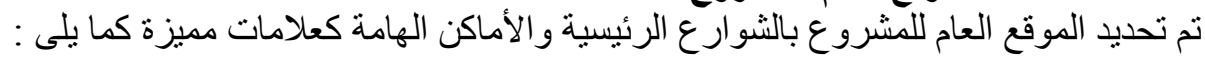

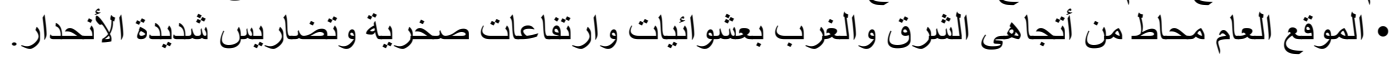

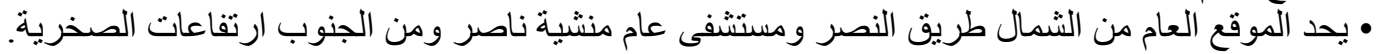

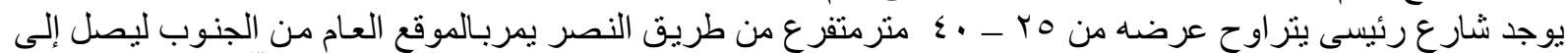

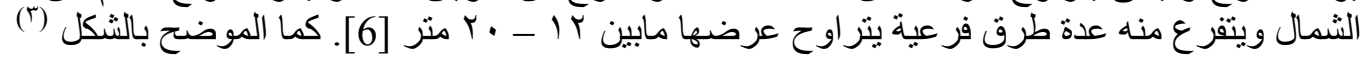



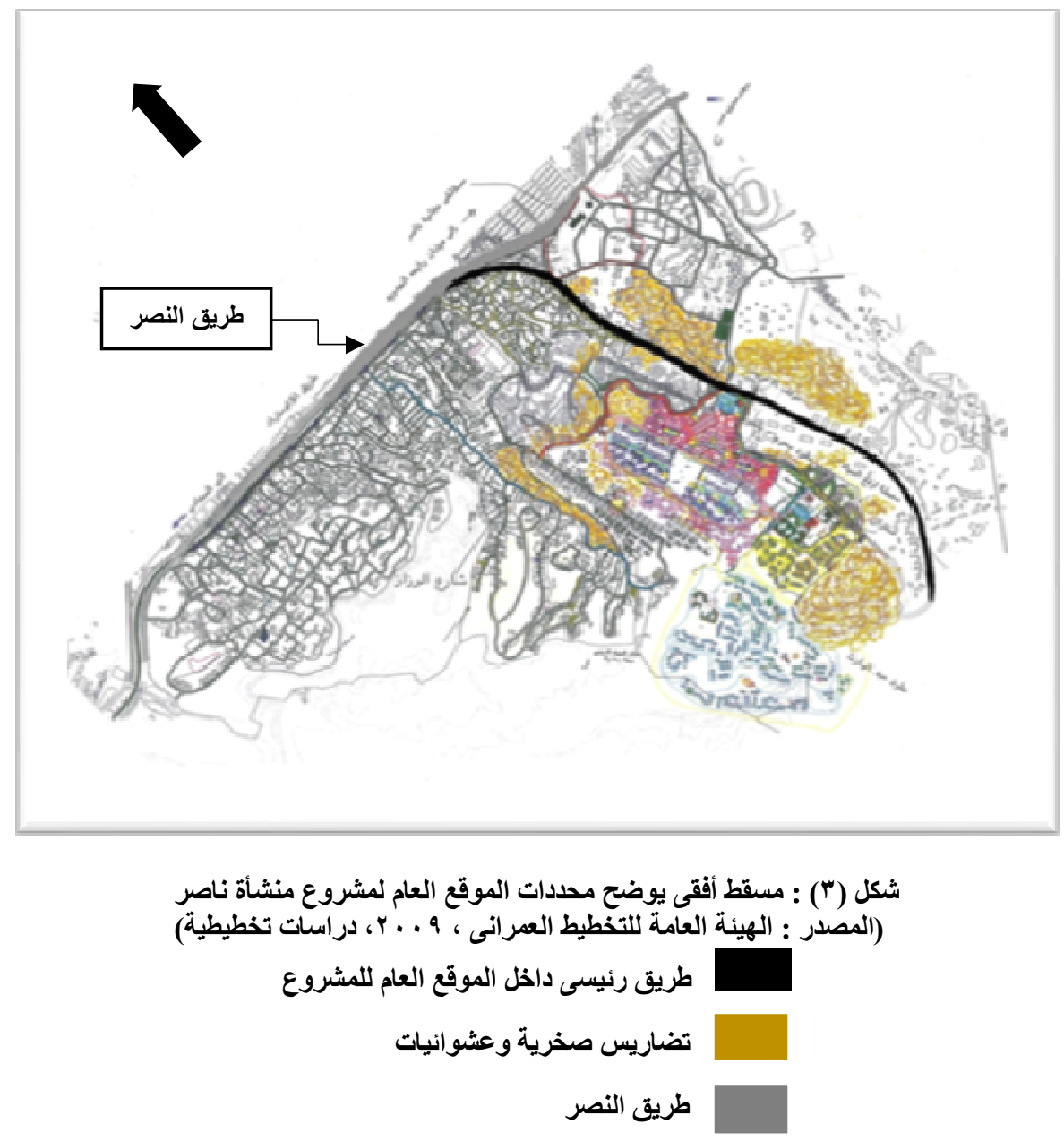

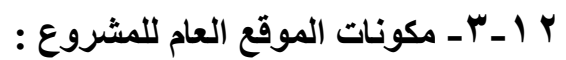

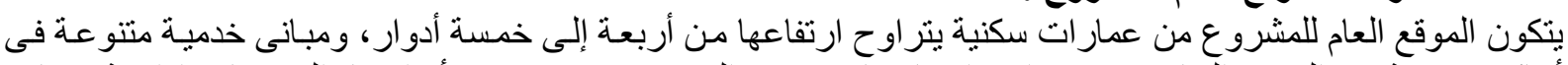

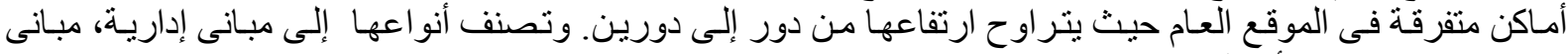

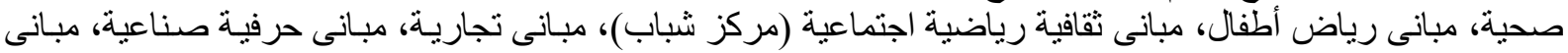

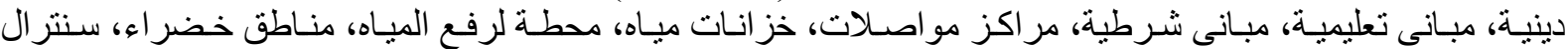

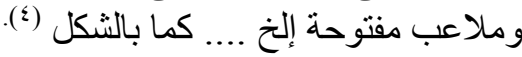




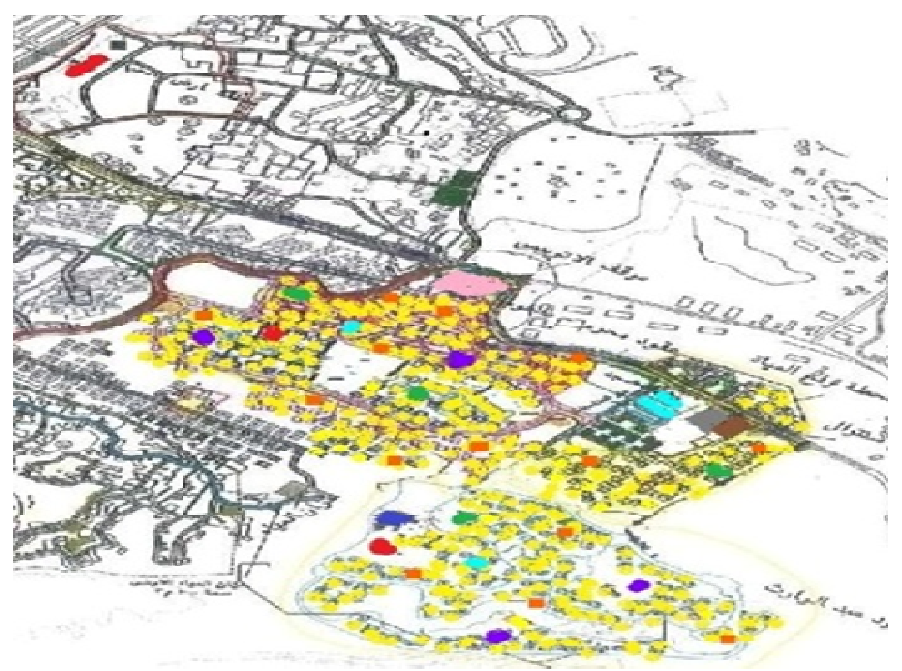

شكل (؛) : مسقط أفقى يوضح مكونات الموقع العام لمشروع منشية ناصر

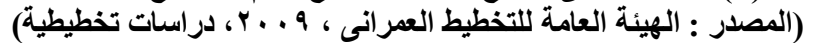
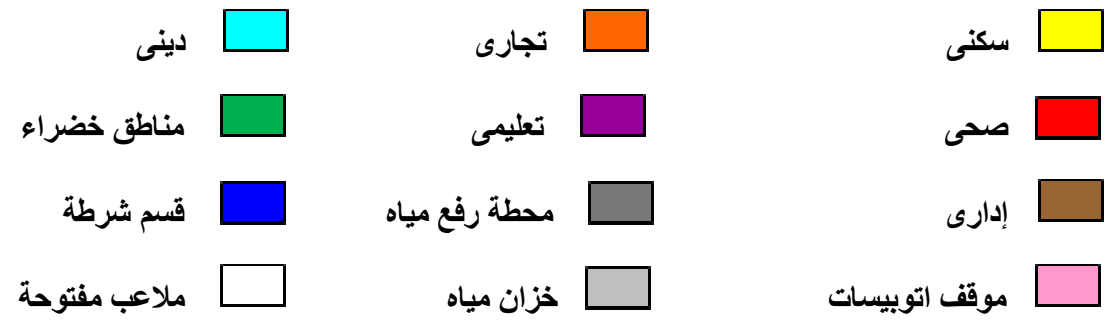

r ا ـ ـ ـ تحديد نماذج المبانى الخدمية حالات الاراسة : تم فى هذا البحث تحديد بعض المبانى النماذج للمبانى الخدمية حالات الدر استة والتى قد استجد عليها حالات تغيير مختلفة فى مرحلة

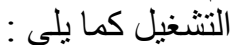
• • • • • مبنى مبنى دار الحضانة البريد

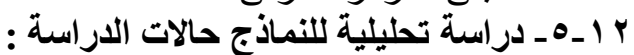

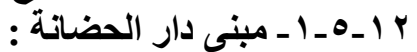

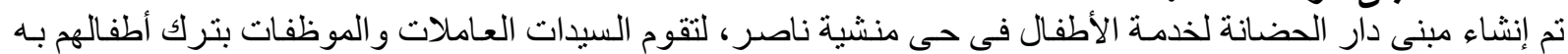

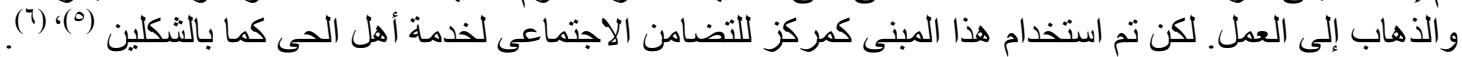
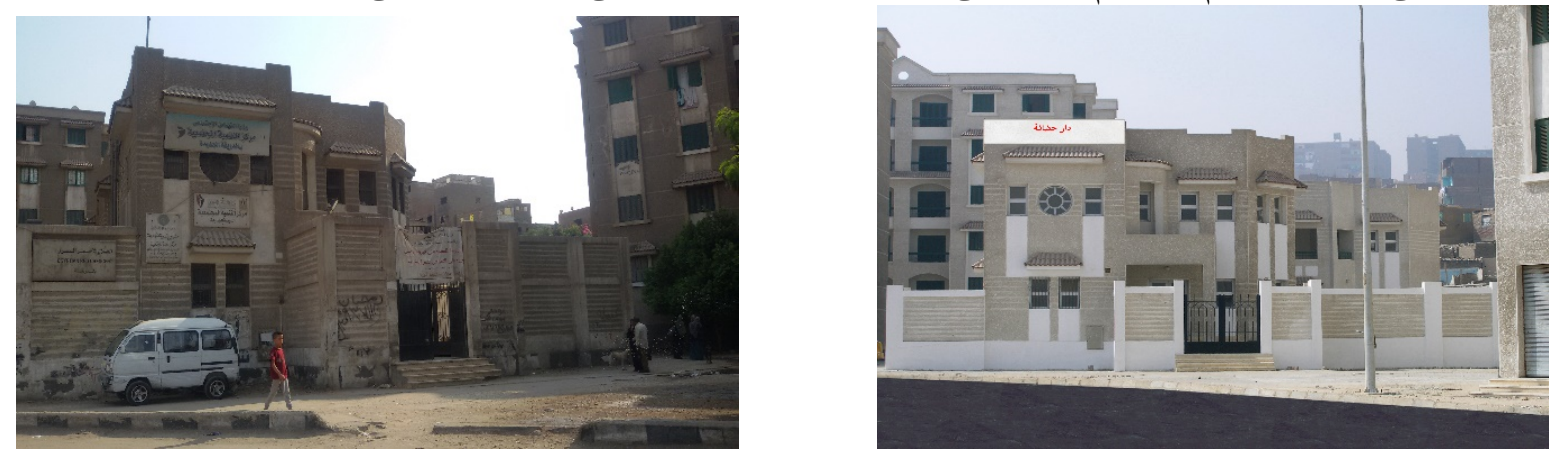

شكل (؟) : مبنى مركز التضامن الاجتماعى

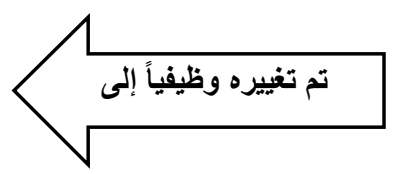

شكل (0) : مبنى دار الحضانة 


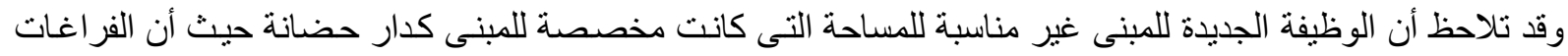

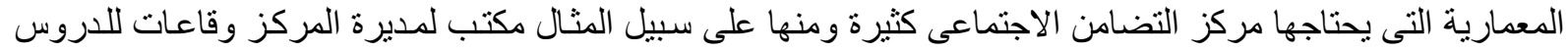

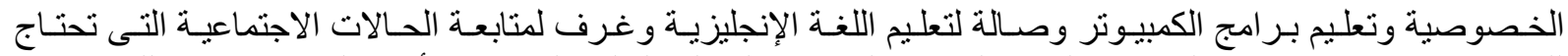

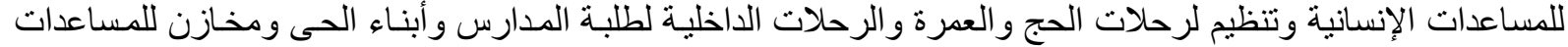

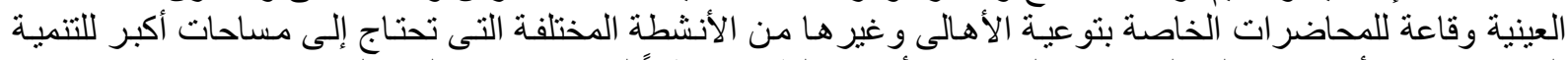

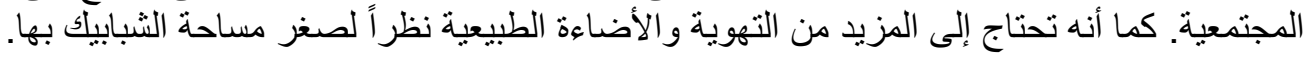

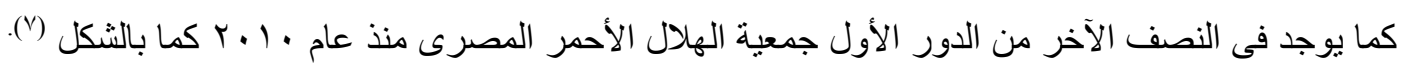

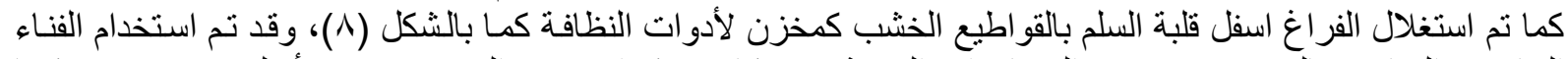

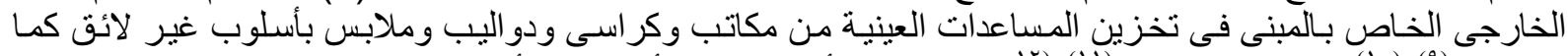

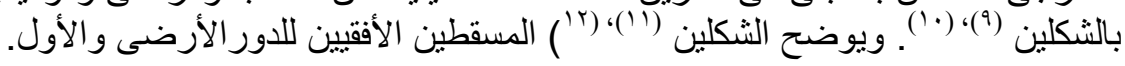

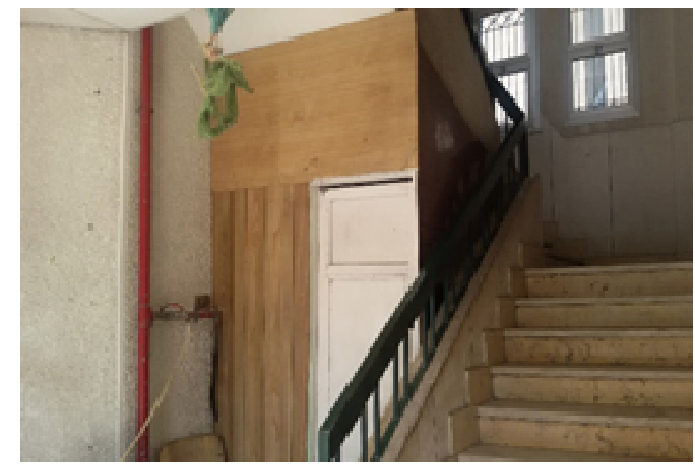

شكل (^) : استغلال الفراغ أسفل قلبة السلم كمزن للأدوات

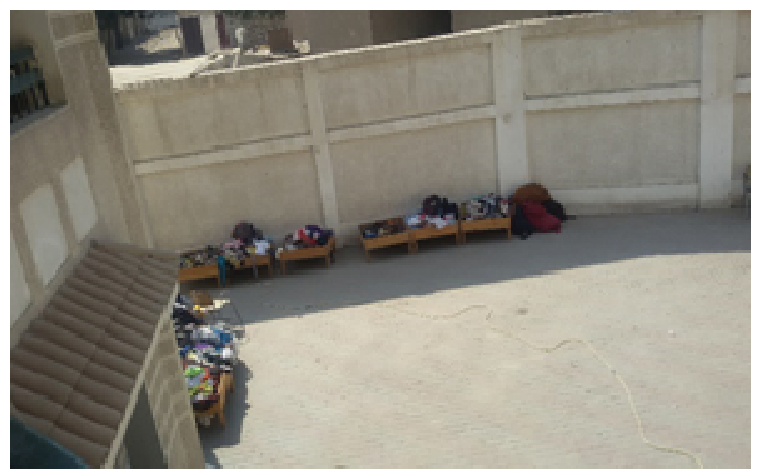

شكل ( • () : تخزين المساعدات العينية من الملابس فى الفناء الخارجى

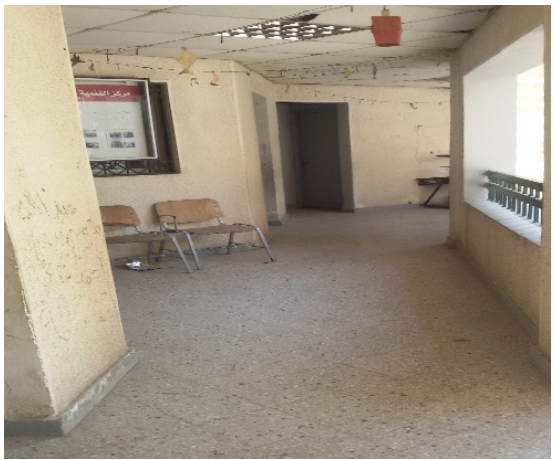

شكل (V) : جزء جمعية الهلال الأحمر المصرى

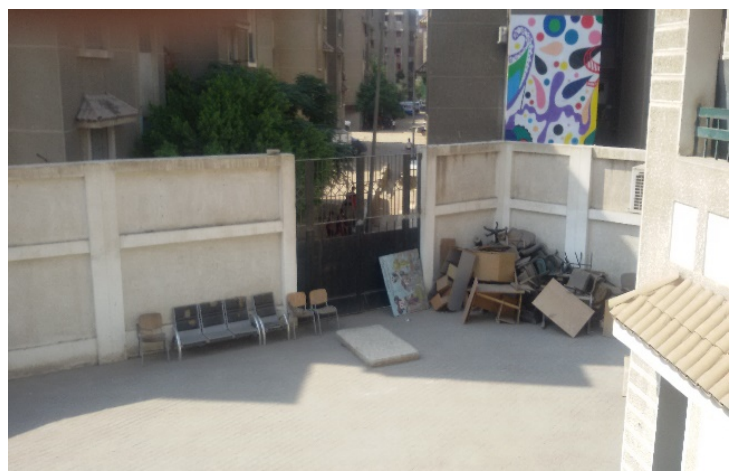

شكل (9) : تخزين الكراسى والمكاتب فى الفناء الخارجى 


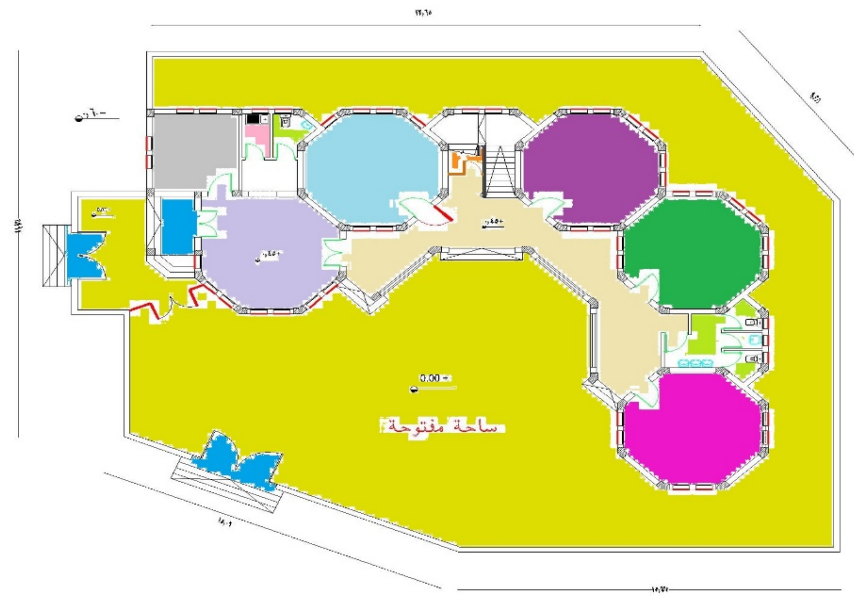

شكل ( (1) : المسقط الأفقى للاور الأرضى بمبنى دار الحضانة بعد تغييره إلى مركز التضامن الاجتماعى وتركيب حديد كريتال على الثبابيك

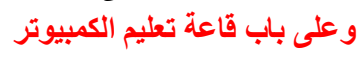

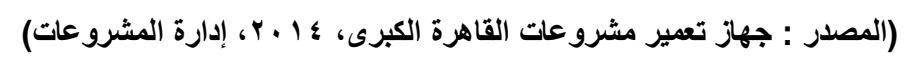

口 مداخل المركز $\square$

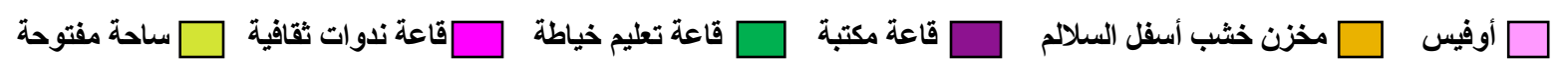

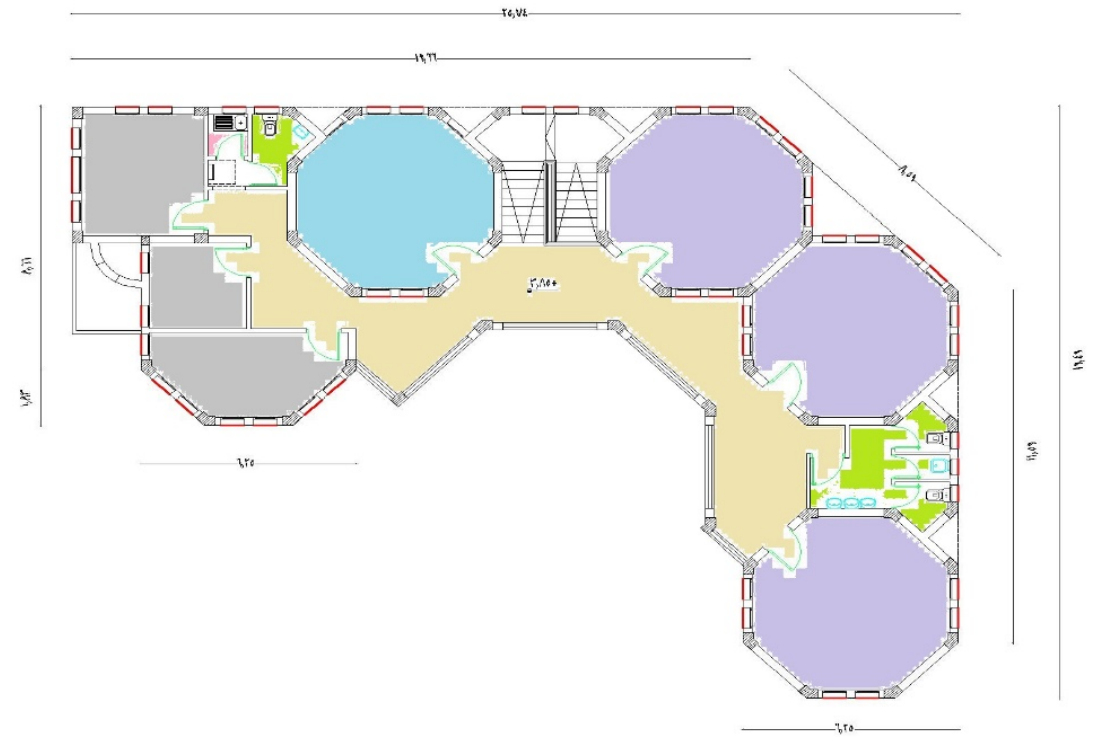

شكل (r ا) : المسقط الأفقى للاور الأول بمبنى دار الحضانة بعد تغييره إلى مركز التضامن الاجتماعى + جمعية الهلال الأحمر المصرى

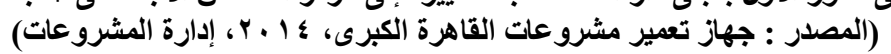

قاعات للاروس التعليمية

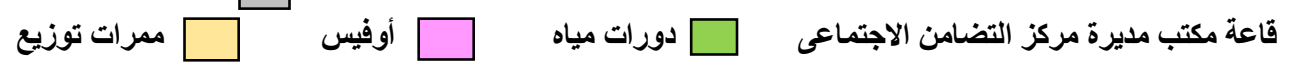

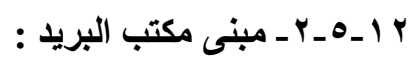

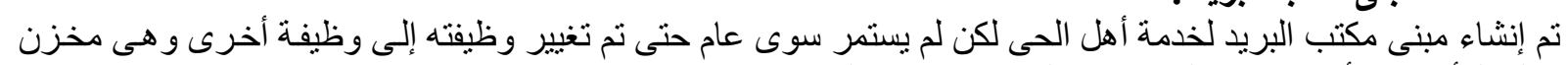

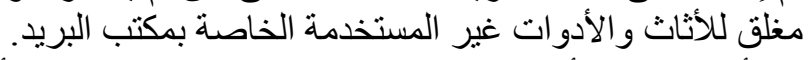

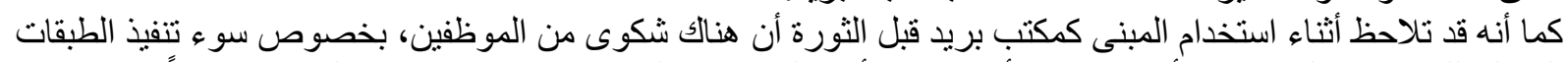

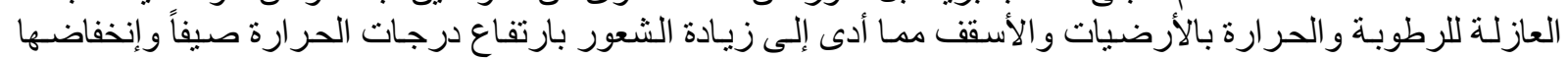

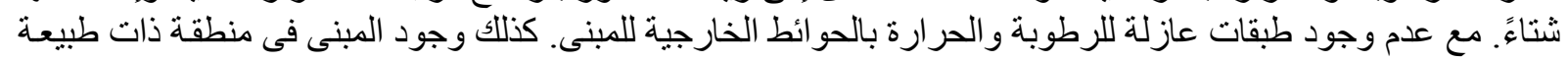




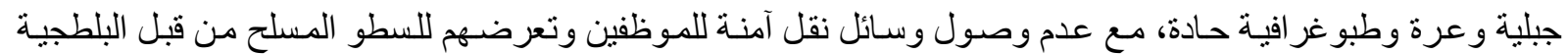

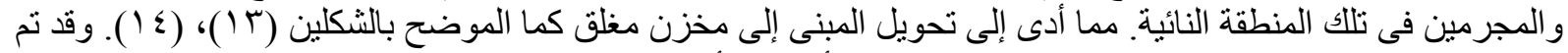

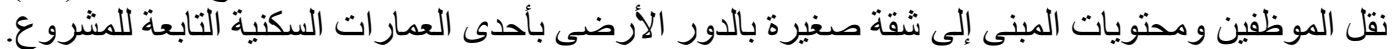

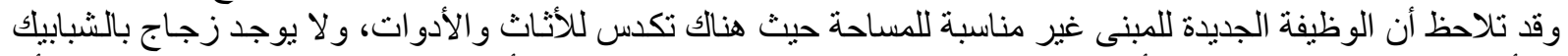

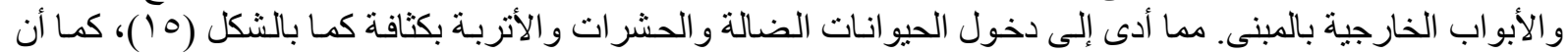

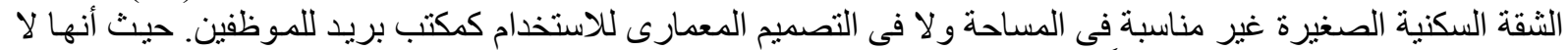

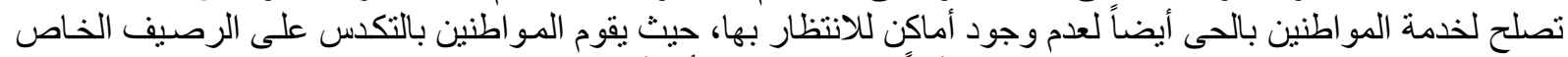

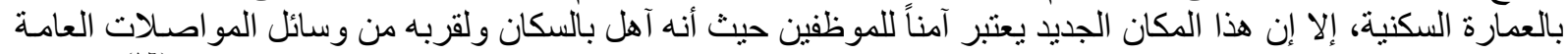

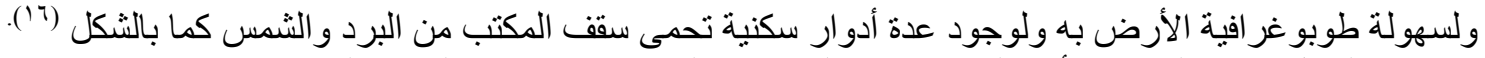
ويوضح الثكل (V V ) المسقط الأفقى لمبنى مكتب البريد بعد التغيير و الإضافيات السابقة الذكر.

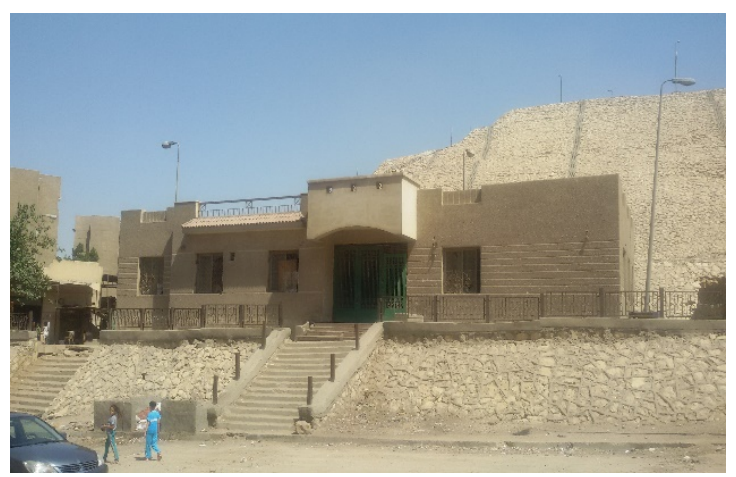

شكل (ع 1 ) : مبنى مخزن مغلق وتركيب الكريتال على الثبلبيك والأبواب

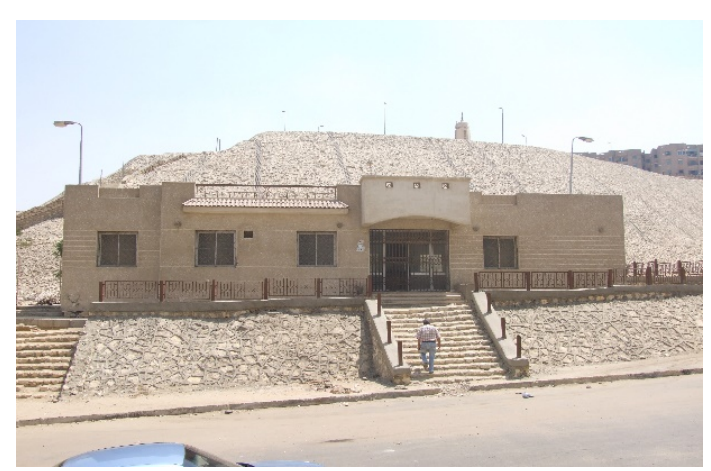

شكل (r I ) : مبنى مكتب البريد بمنطقة جبلية وعرة تم تغييره وظيفياً إلى

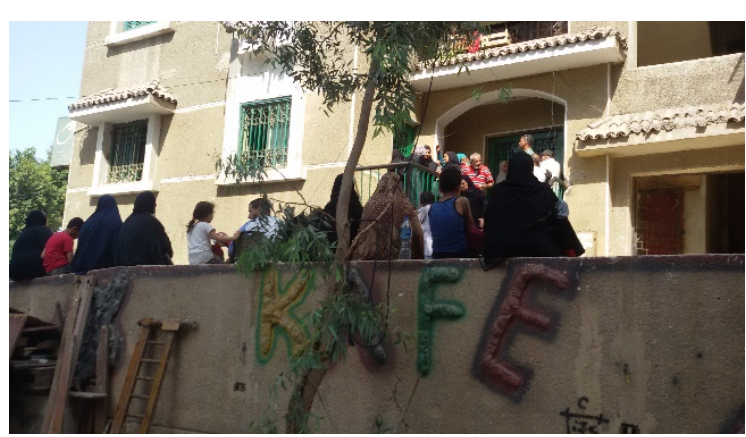

شكل (7 1 ) : تكلس الجمهور أمام مكتب البريد بالثقة الصغيرة بالعمارة

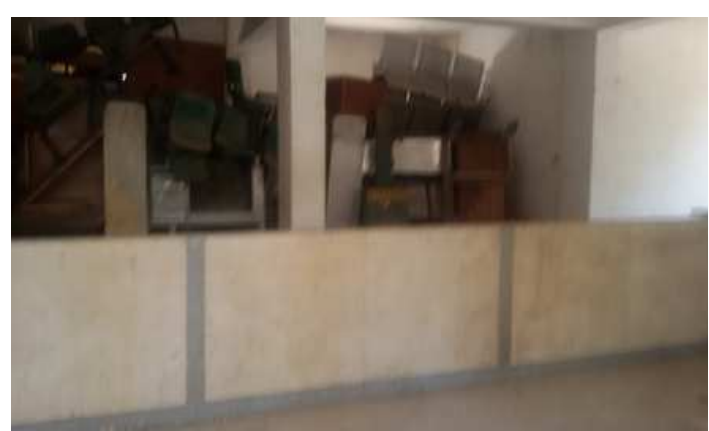

شكل (0 1 ) : مبنى المخزن المغلق وتكدس الأثاث والأتربة

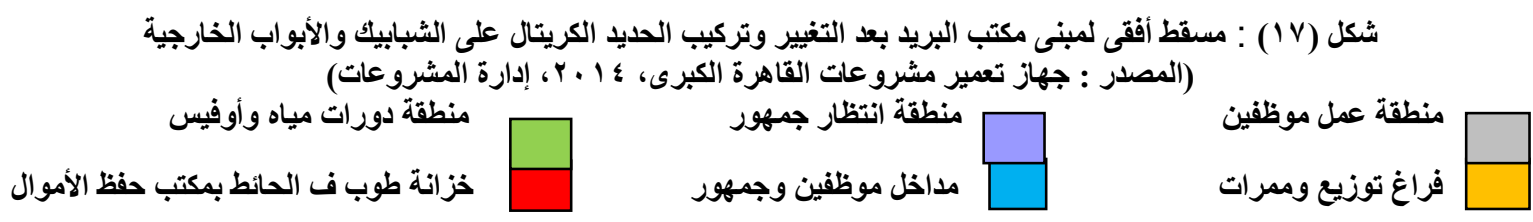

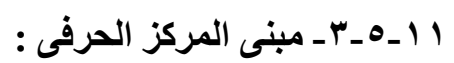

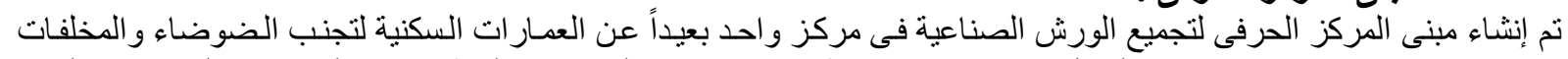

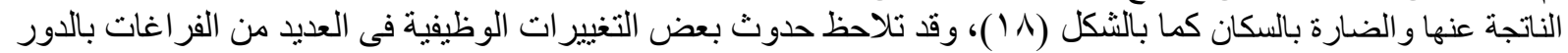

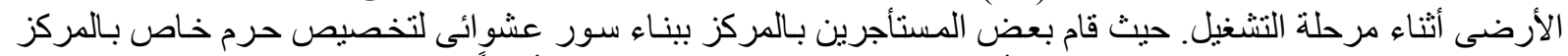

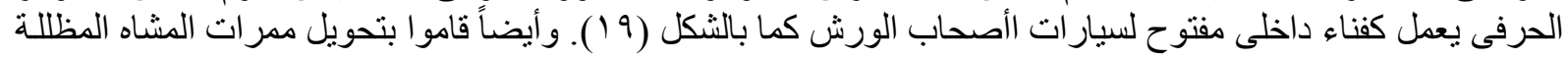




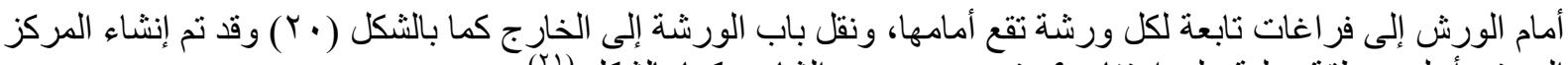

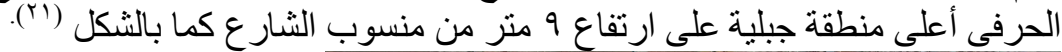

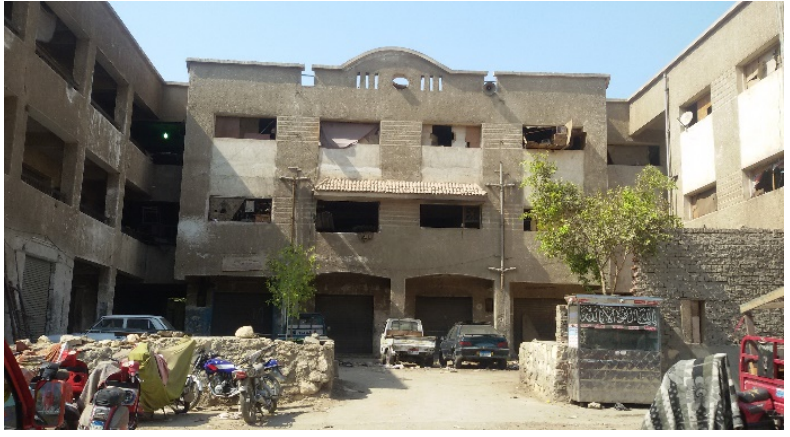

شكل (9 (1) : مبنى المركز الحرفى للورش بعد التثغيل والتغييرات

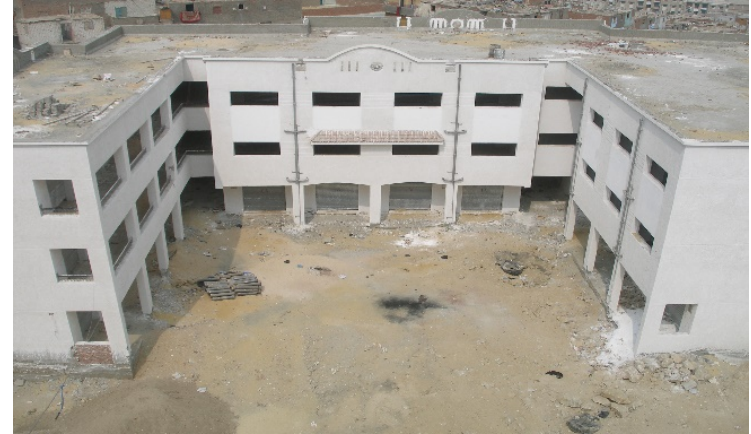

شكل (11 ) : مبنى المركز الحرفى للورش قبل التشغيل

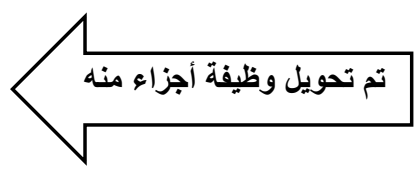

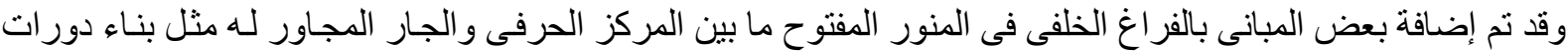

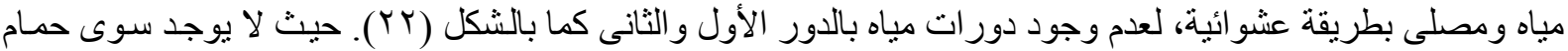

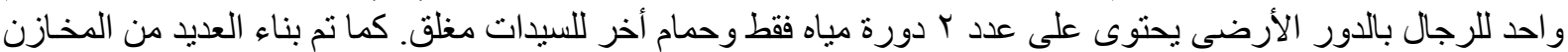

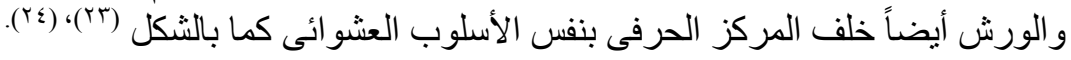
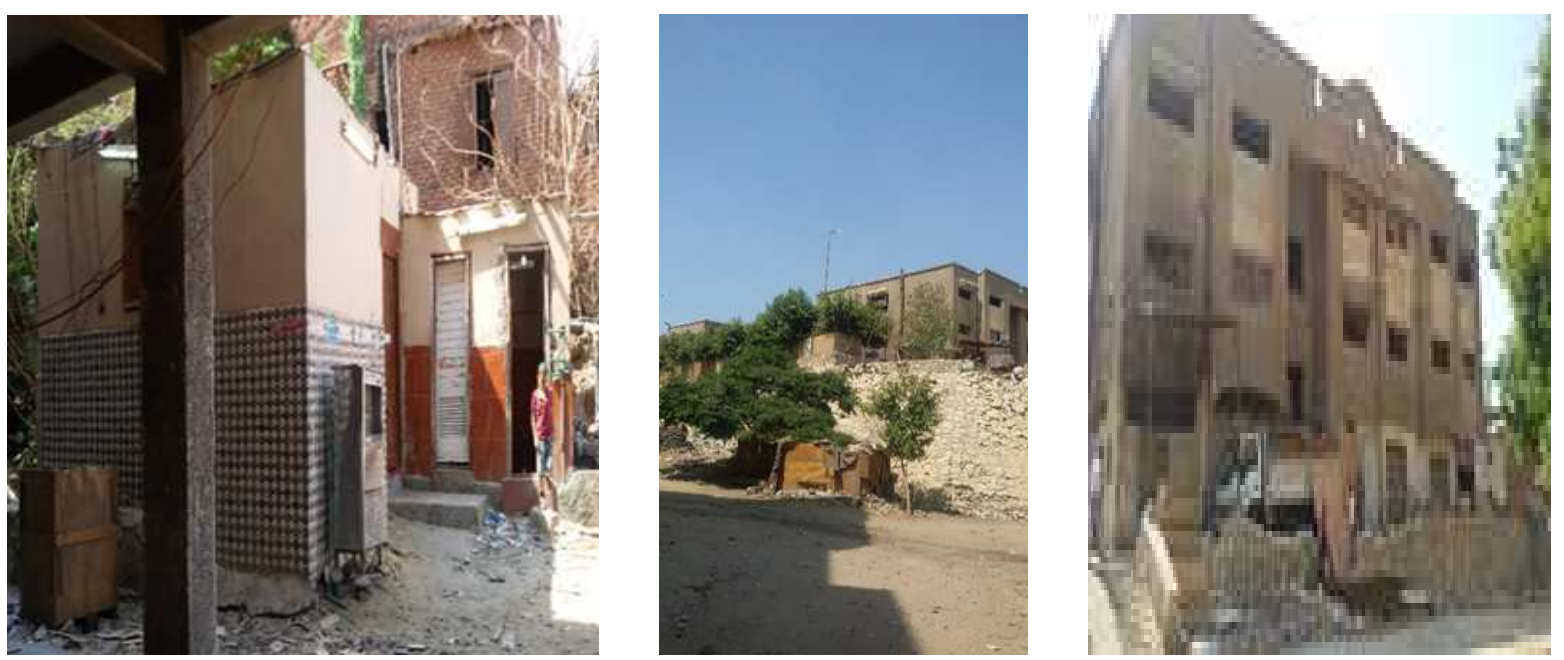

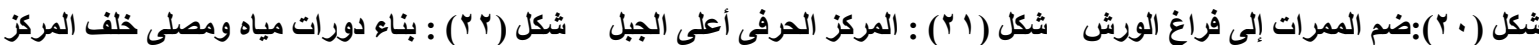

كما تم استغلال الفر اغات اسفل قلبات السلالم وبناء ورش عشو ائية مخالفة واستغلال فر اغ مدخل السلم فى المبنى فى أعمال

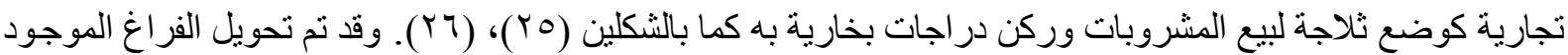

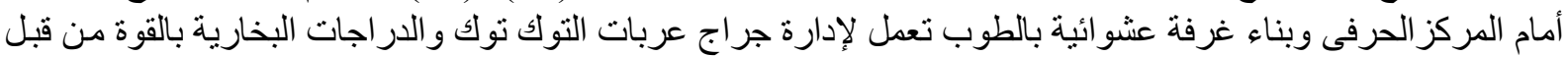

أحد البلطجية كما بالثكل (rv) 
التغيير الوظيفي لفر اغات المباني الخدمية و أثره في مرحلة التشغيل

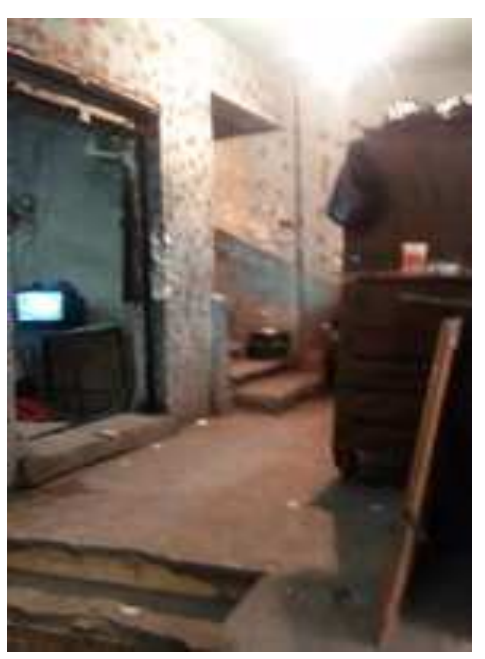

شكل (ro) : بناء ورشة أسفل قلبة السلم

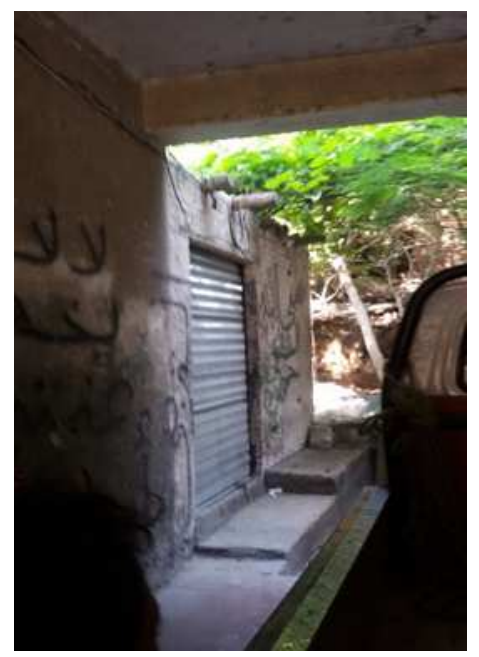

شكل (乡 ץ) : بناء ورشة خلف المركز

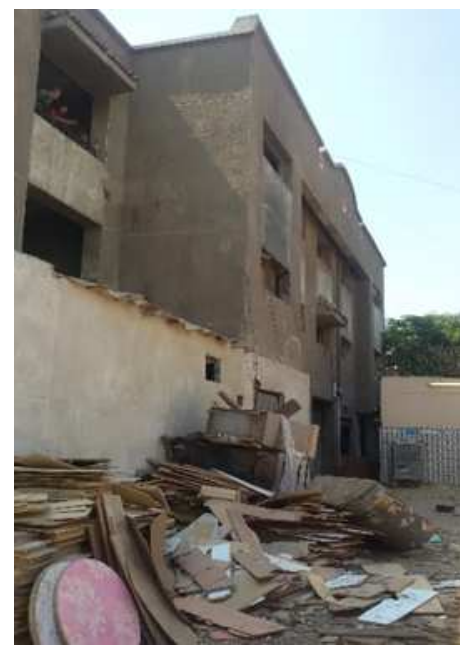

شكل (بَץ) : بناء مخزن خلف المركز
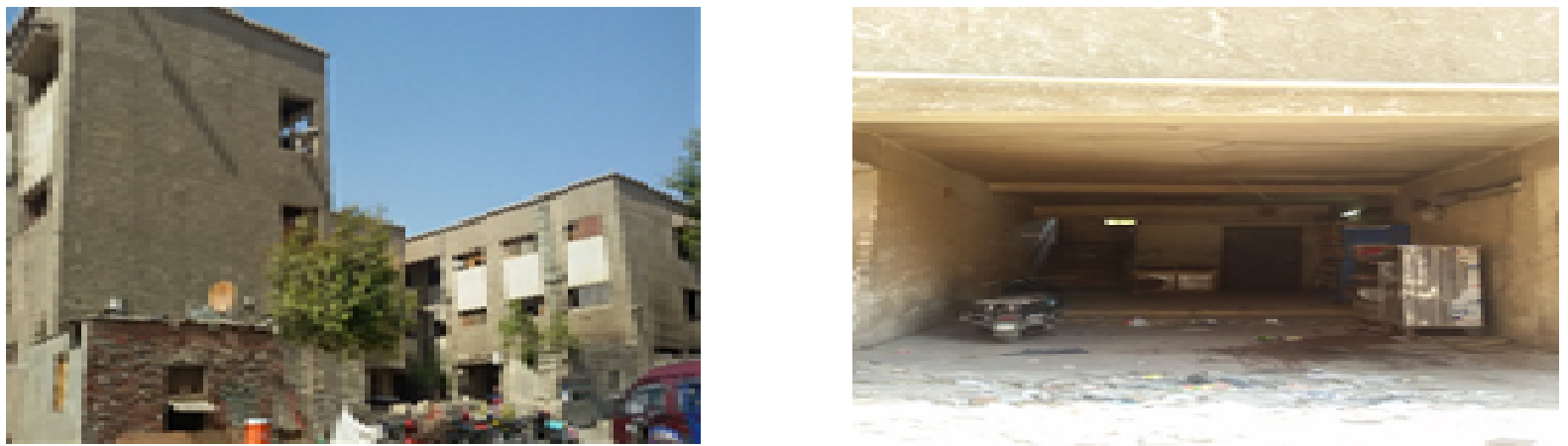

شكل (rV) : بناء غرفة عثوائية أمام المركزلإدارة جراج التوك توك شكل (צr) : أغراض تجارية وركن دراجات بخارية بمدخل السلم

ويوضـح الشكل (Y^) المسقط الأفقى للـور الأرضسى لمبنى المركز الحرفى للورش الصناعية بعد التغيير والإضـافات

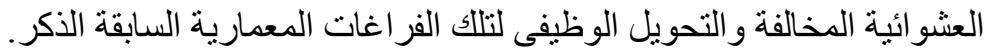




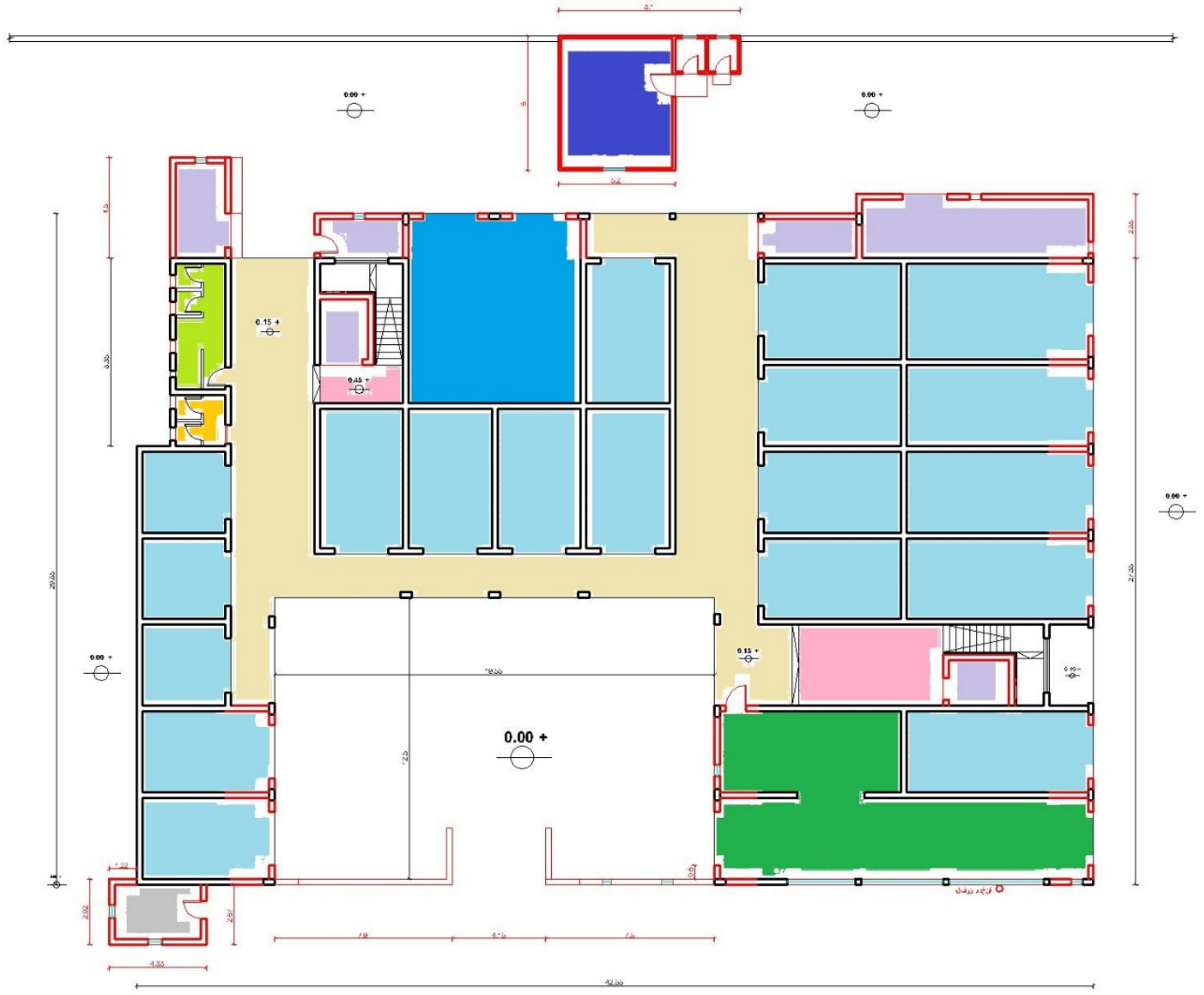

شكل (Y^) : المسقط الأفقى للاور الأرضى لمبنى المركز الحرفى للورش بعد التغيير ويناء حوائط ومبانى مخالفة وعشوائية (المصدر : جهاز تعمير مشروعات القاهرة الكبرى، ؛ ا ب ؟، إدارة المشروعات)

مبانى طوب عثوائية بالسور المحيط بساحة المركز الحرفى + مبانى طوب لتوسعة الورش الحرفية لضم الممرات المسقوفة للورش

محلات عشو ائية تم بنائها أسفل قلبات السلالم وخلف المركز الحرفى مصلى تم بنائها عشو ائياً ويجوارها حمامين للوضوء خلف المركز الحرفى غرفة عشوائية لإدارة جراج التوك توك أمام المركز الحرفى

ورشتين حرفيتين مفتوحين على بعض بعد هلم الحائ الفاصل بينهما ثلاثة ورش حرفية تم هلم بعض الحوائط الفاصلة بينهم لعمل مخبز للعيش ورش حرفية كل منها مستقلة عن الأخرى حمام رجالى واحد فقط للمركز الحرفى كله المكون من ثلاثة أدوار حمام حريمى واحد فقط ومثلق غير مستخدم ممرات مسقوفة أمام الورش الحرفية مداخل السلالم المؤدية للأدوار العليا

إ إ ـ ـ التحليل الوظيفى للمبانى الخدمية القائمة :

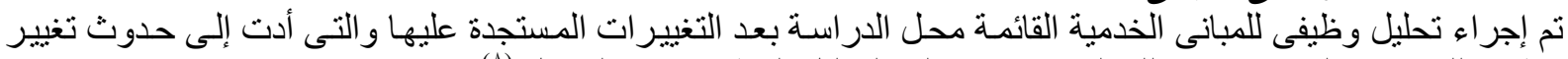

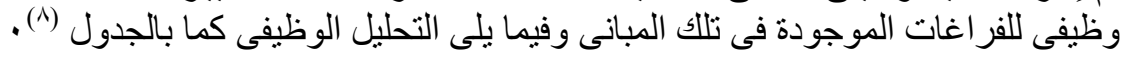


جدول (^) : التحليل الوظيفى للمبانى الخدمية القائمة بعد التغيير

\begin{tabular}{|c|c|c|c|c|c|}
\hline الحرفيى اللورشز & مبني مكتب & مبنى دارة & \multirow{3}{*}{\multicolumn{3}{|c|}{ عناصر التحليل الوظيفى }} \\
\hline تُ تُ تحويل وظنه إلى & تم تغييره وظيفياً & تم تغييره وظيفياً & & & \\
\hline الحرفي اللورشز & مبنى مخزن & التضامن مركز & & & \\
\hline مناسبة & غير مناسبة & غير مناسبة & \multicolumn{2}{|c|}{ أهداف إنشاء المبنى بعد التغيير } & \multirow{9}{*}{ المعاناًا } \\
\hline $\begin{array}{l}\text { ارتفاع فو اتير } \\
\text { الكهرباء }\end{array}$ & ل لا يوجد & زيادة الفر اغات & الموظفين/ العمال & \multirow{6}{*}{ المعلومات الخاصحة } & \\
\hline لايوجد & ل الا يوجد & زيادة أماكن & الجمهور & & \\
\hline غير متو افرة & غير متو افرة & متو افرة & النو احى الأمنية & & \\
\hline 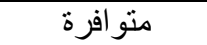 & 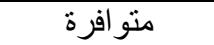 & 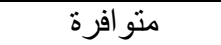 & شبكات المر افق & & \\
\hline متو افرة & متو افرة & مناسبة & 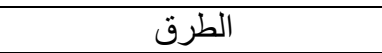 & & \\
\hline غير متو افرة & غير منو افرة & منو افرة & وسائل المو اصلات العامة & & \\
\hline تم مر اعاتها & ل لا يوجد & لتعدد يتم مر الأشطة بها & \multicolumn{2}{|c|}{ تحديد طبيعة العمل القائمة داخل الفر اغات } & \\
\hline 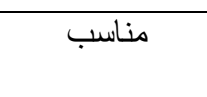 & ل لا يوجد & للفر اغتر من المحداتد & \multicolumn{2}{|c|}{ عدد المستخدمين المطلوب إنشالهم للفر اغات } & \\
\hline غير آمن & غير آمن & مناسبة و آمنة & \multicolumn{2}{|c|}{ الموقع العام للمبنى و الأرض المحيطة به } & \multirow{14}{*}{ تانيلًاً } \\
\hline وعرة وصعبة & وعرة وصعبة & مستوية & طوبو غر افية الأرض & \multirow{6}{*}{ تحديد خصائص } & \\
\hline مناسبة & مناسبة & مناسبة & محاور الدخول والخروج & & \\
\hline كافية & كافية & غير كافية & المساحة & & \\
\hline غير متكاملة & غير منكاملة & متكاملة & المحتويات & & \\
\hline مناسبة & مناسبة & مناسبة & 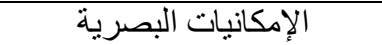 & & \\
\hline 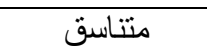 & متتاسق & 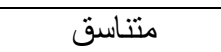 & الثكل العام & & \\
\hline كافية & كافية & كافية - كافي & المنطقة المشاعية & \multirow{3}{*}{ تلأجزيم الموقع العامية } & \\
\hline غير كافية & كافية & غير كافية & المنطقة الخدمية & & \\
\hline كافية & كافية & كافية & المنطقة الذاتية & & \\
\hline منو افر & متو افر & منو افر & جزء مخصص للمبنى & \multirow{4}{*}{ توزيع الاستخدامات } & \\
\hline منو افر & غير متو افر & غير متو افز & جز ء مخصص للسيار ات & & \\
\hline غير متو افز & متو افر & 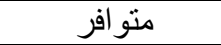 & جز ع مخصص للمشاه & & \\
\hline لا يوجد للمياه & لا لا يوجد للمياه & لا لا يوجد للمياه & جزء للأشجار و النباتات و المياه & & \\
\hline مناسبة & مناسبة & مناسبة & حركة المستخدمين داخل الفراغ & \multirow{5}{*}{ تحديد المكونات } & \multirow{13}{*}{ التوزيعاً } \\
\hline مناسبة & مناسبة & مناسبة & مقاييس المستخدمين & & \\
\hline متو افرة & متو افرة & متو افرة & التهوية و الإضـاءة الطبيعية & & \\
\hline مناسبة & مناسبة & مناسبة & أماكن الثبابيك و الأبو اب & & \\
\hline متكامل & غير متكامل & متكامل & الفر اغ الخارجى & & \\
\hline مناسبة & مناسبة & غير مناسبة & \multicolumn{2}{|c|}{ تحديد المسطحات و المعايير التصميمية طبقاً للآكو اد } & \\
\hline مناسبة & مناسبة & غير مناسبة & \multicolumn{2}{|c|}{ العلاقات الر ابطة بين المكونات المعمارية } & \\
\hline متو افرة & متو افرة & متو افرة & عناصر الحركة الأفقية & \multirow{2}{*}{ المكونات المركمى فىية } & \\
\hline متو افرة & 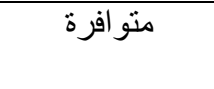 & مطلوب سلم & عناصر الحركة الرأسية & & \\
\hline مراوح & مراوح & مر اوح وتكييفات & التهوية الصناعية & \multirow{4}{*}{ 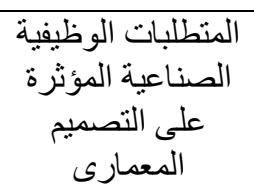 } & \\
\hline مناسبة & غير مناسبة & مناسبة & الإنارة الصناعية & & \\
\hline مناسب & غير مناسب & مناسب & العزل الحرارى & & \\
\hline 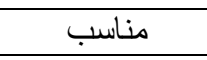 & غير مناسب & 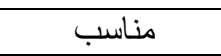 & العزل ضد الرطوبة & & \\
\hline
\end{tabular}

(Resource : Yin R K, 2012, “Case Study Research : Design And Methods“, USA.)

(المصدر : الباحثة) 
با 1 ـ الإستراتيجية المقترحة لرفع كفاءة الأداء الوظيفى للمبانى الخدمية القائمة حالات الدراسة :

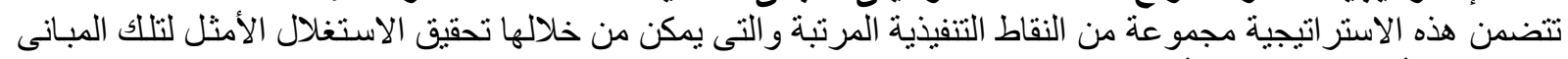

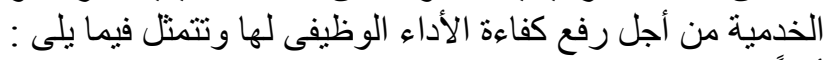

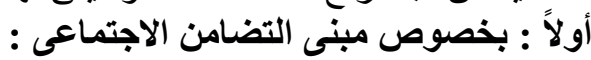

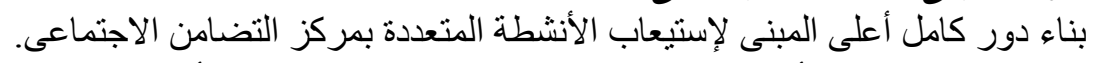

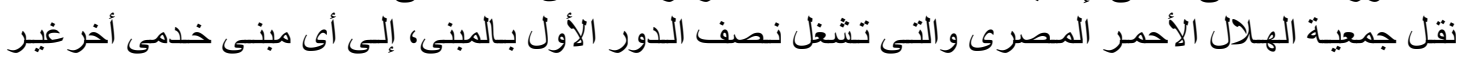

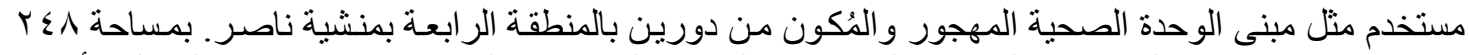

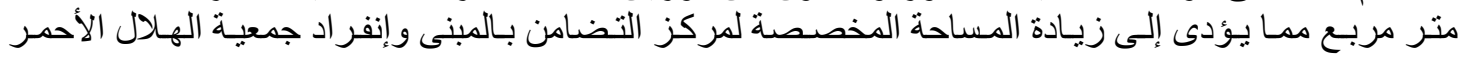

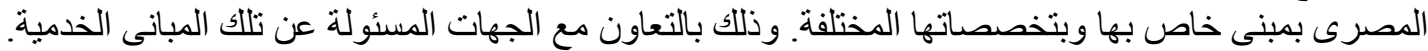

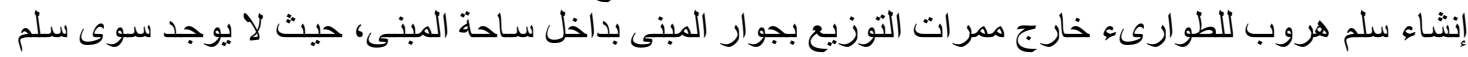
رئيسى و احد فقط بالمبنى.

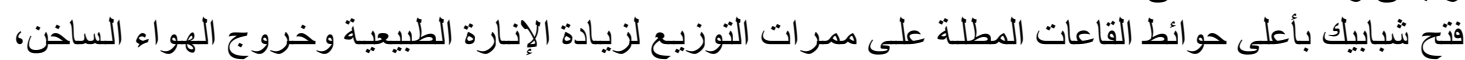

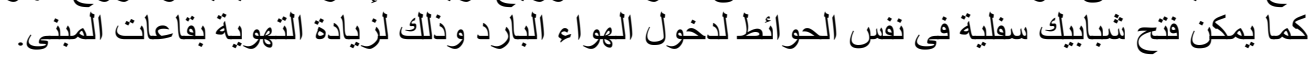

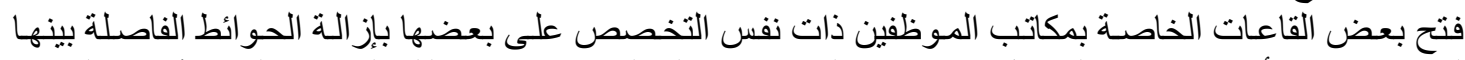

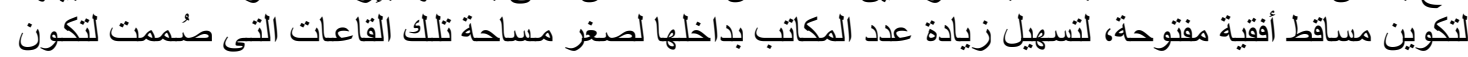

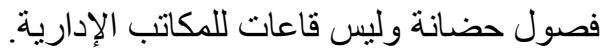
ثانياً : بخصوص مبنى مكتب البريا :

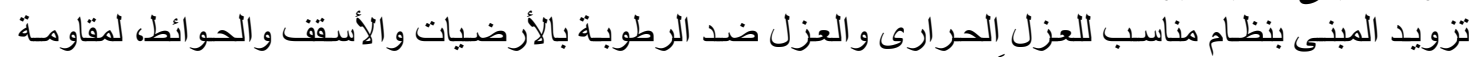

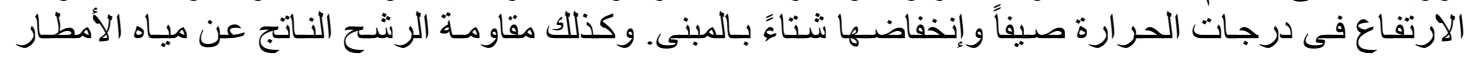

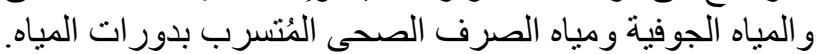

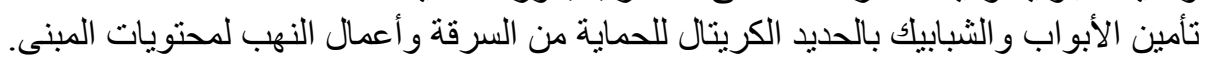

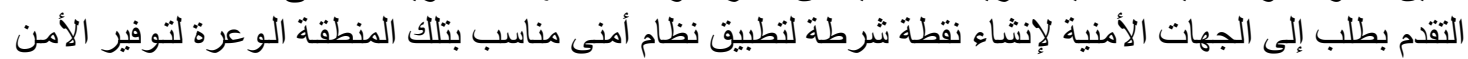

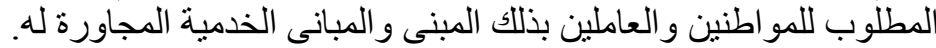

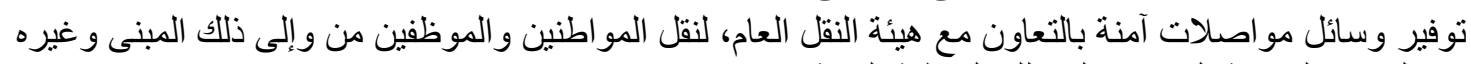

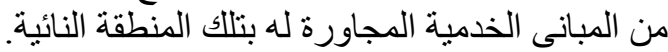

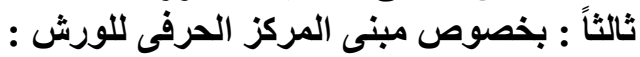

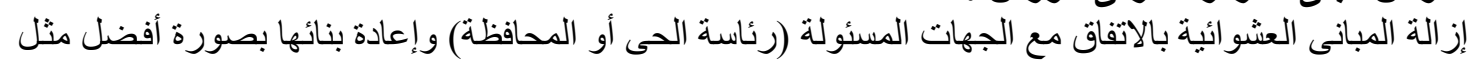

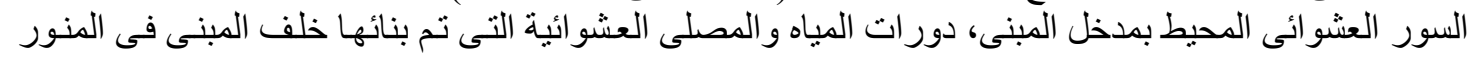

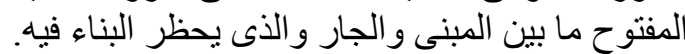
توسعة وتطوير دور المات المياه الموجودة بالدور الأرضى فئه وإجر اء أعمال الصيانة المناسبة لها لخدمة أكبر عدد من

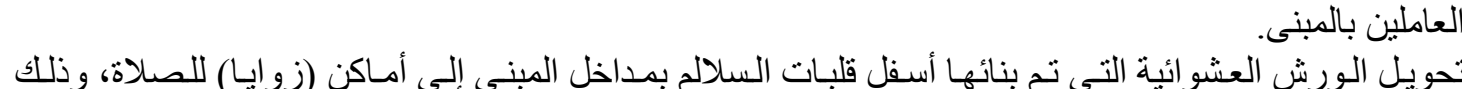
بالاتفاق مع الجهات المسئولة السابقة الذكر.

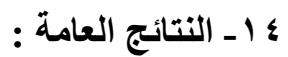

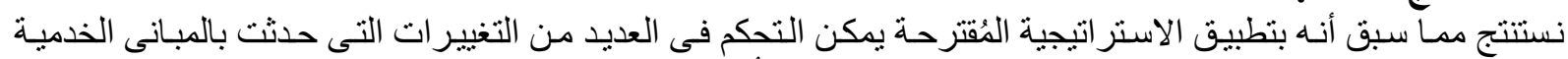

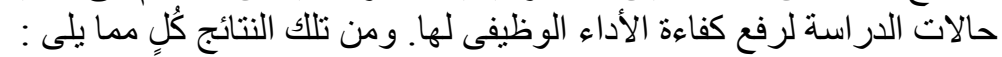

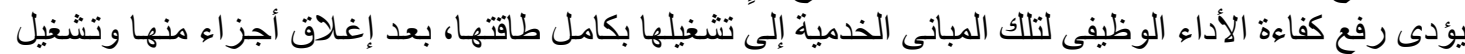
إجز اء أخرى أو إغلاقها بالكامل أو تركها مهجورة الوفان.

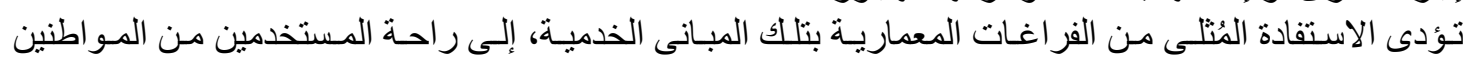

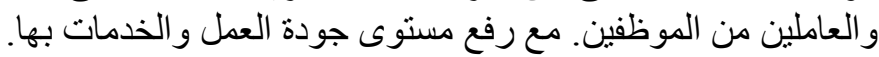

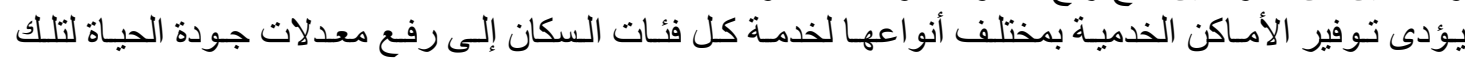

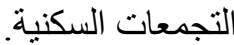

ليؤدى توفير المبانى الخدمية الناجحة بقلب التجمعات السكنية بالمشروع إلى توفير الكثير من الوقت والمال و الجهد

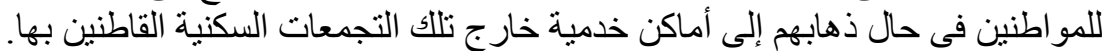

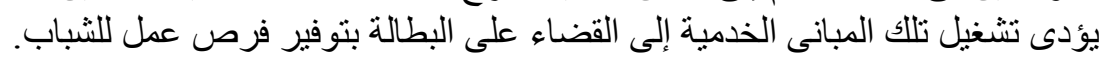

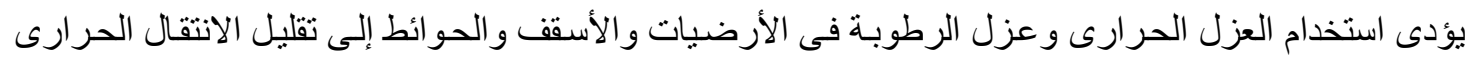

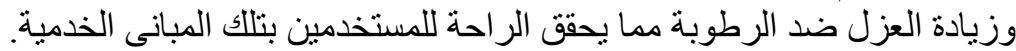
يؤدى زيادة الثبابيك العلوية بالحو ائط المطلة على ممرات التوزيع إلى توفير الإضاءة و التهوية الصناعية بالمبنى. 
يؤدى تطبيق نظام المساقط الأفقية المفتوحة إلى زيادة المساحة وتوفير العديد من المكاتب وسهولة مر اقبة العمل بها

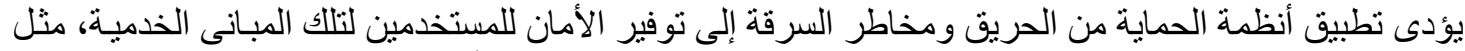
توفير سلالم للهروب في الطوارئ وتركيب الحديد الكرينال على الثبابيك و الأبو الباب.

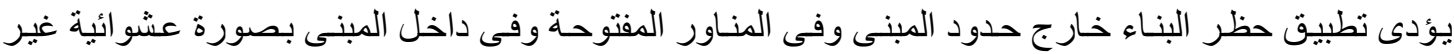

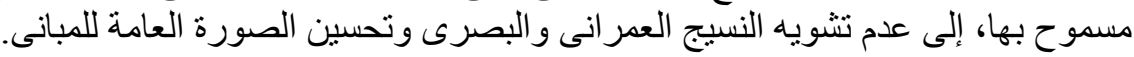

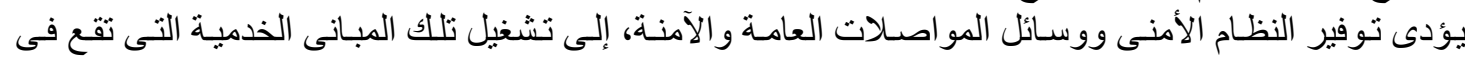
مناطق نائية و إقبال المو اطنين عليها و الافني ووسيات الاستفادة منها.

• • حظر البناء خارج حدود المبانى وفى المناور المفتوحة ما بين المبانى وبعضها.

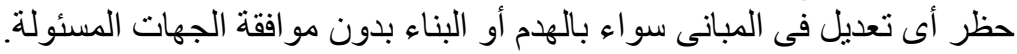

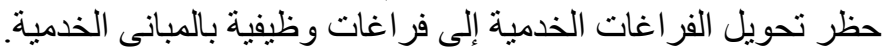

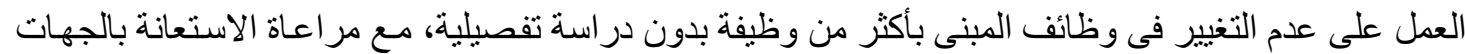
الاستشارية الخارجية المُتخصصية.

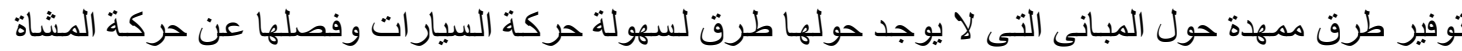

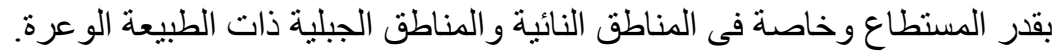

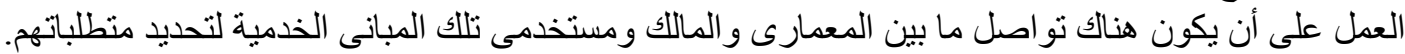

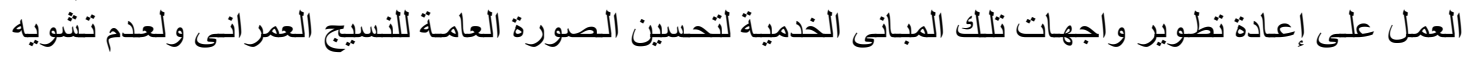

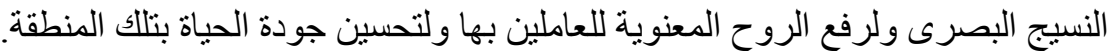

1. أبو الخير ، كمال، ع . . Y، " التنظيم و إدارة الجودة الثاملة المتو اصلة "، القاهرة، الناشر مكتبة جامعة عين شمس.

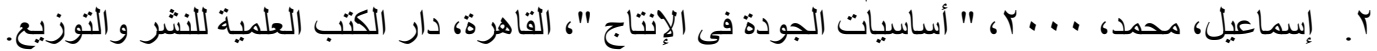

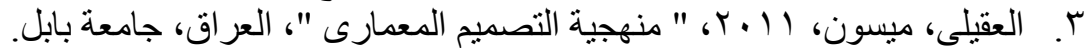

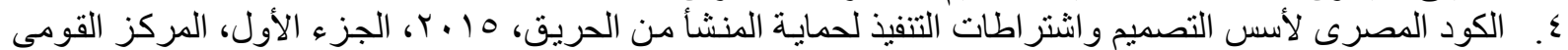
لبحوث الإسكان و البناء، جمهورية مصر الإنمر العربية.

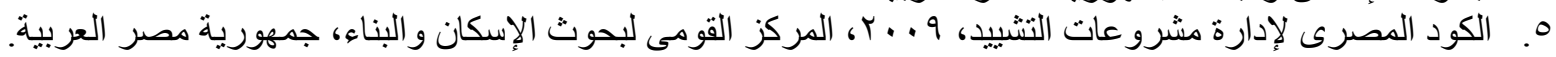

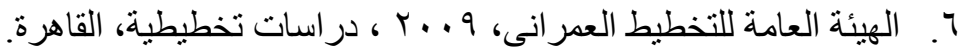

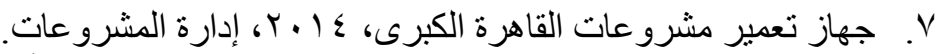

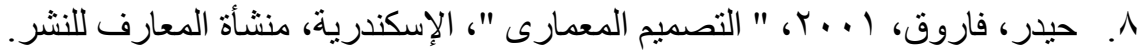

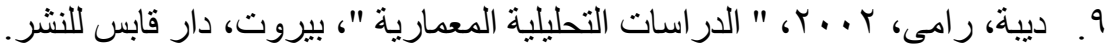

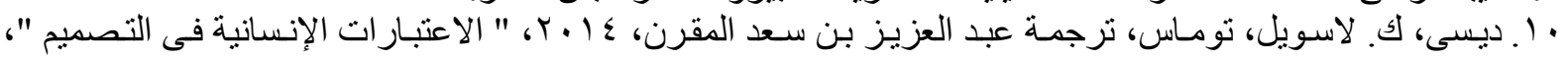

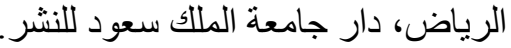

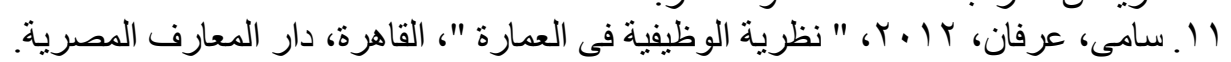

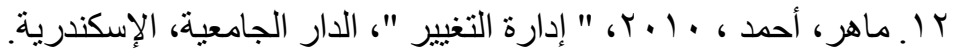

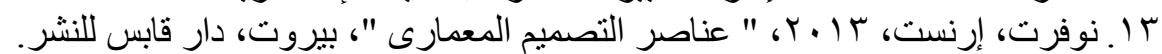

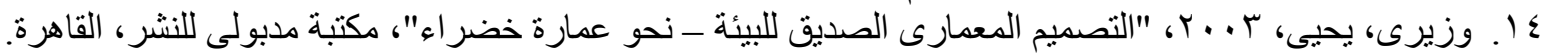

15.Baiche, B. 2011, “Neufert, Architects' Data”, Germany, Publisher, l'autor.

16. Binggeli, C. 2004, "Building Systems For Interior Designers", USA, John Wiley \& Sons INC

17. De Chiara, J. 2000, "Time Saver For Building Types“, USA, Braun Press.

18. Ebbert, Thiemo, 2010, "Re - face Refurbishment Strategies For The Technical Improvement Of Office Façade", Germany, Publisher, l'autor .

19. Paradis, Richard, 2016, "Retrofitting Existing Buildings To Improve Sustainability And Energy Performance", ProQuest, UMI Dissertation Publishing, USA.

20. Ragheb, Amany, 2016, “ Design Of Office Building “,El Mansora, Egypt, Publishing In Design.

21. Riewoldt, O \& Hudson, J. 2014, “New Office Design “, USA, Laurence King Publishing.

22. Rungta, Shaily, ، 2011,"Design Guide: Horizontal Shading Devices And Light Shelves“, Sage Publications, USA.

23. Yin R K, 2012, "Case Study Research : Design And Methods", 4th, Sage Publications, USA. 